\title{
A new era of Global HR Competency Model - Evidence from Global HR Positions
}

*Eyden Samunderu - International School of Management | eyden.samunderu@ism.de Jörg Hruby-Fundação Dom Cabral (FDC) | JHruby@gmx.com

Ingo Roeger | Ingo.roeger.2018@student.ism.de

Jingxian Wang | wangjingxian2012@gmail.com

\begin{abstract}
Aim/Purpose This paper proposes an empirical impact for developing an individual Global Mindset within the Global HR department.

Background We conducted a comprehensive survey by observing 256 responses from 27 different global HR positions on which 75 global competencies are relevant in their day-to-day work.

Methodology Based on this groundwork, the paper makes further attempt by proposing an integrative global HR competency framework whereby we identify development dimensions fundamental for developing global leaders.

Findings Our findings show a top 10 list of the most relevant global leadership mindset (GLM) competencies in Global HR. We further investigated 12 different HR positions and assessed relevant GLM competencies relevant in different global career stages. Our findings show that self-management skills, emotion$\mathrm{al} /$ affective, and cognitive competencies are most important for entry-level positions.

Impact on Society Global leadership skills play a vital role for medium-level positions, and seniorlevel positions require emotional/affective competencies, followed by cognitive aspects.

Keywords Global Mindset, Global Leadership (Competency) Development; Global Human Resources Development, Global Career

Corresponding Author

(C) The Author(s) 2020. Open Access: This article is distributed under the terms of the Creative Commons Attribution 4.0 International License. (https://creativecommons.org/licenses/by-nc/4.0/)
\end{abstract}


Volume 5, 2021

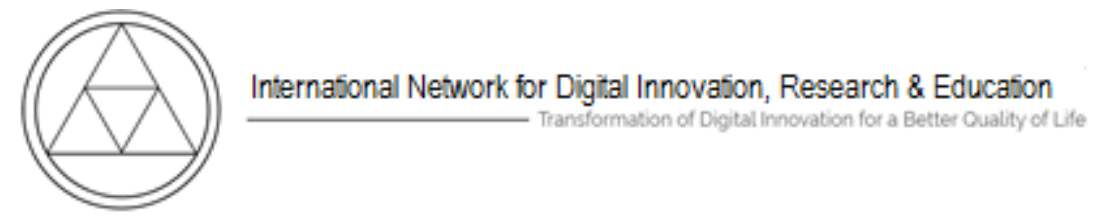

\section{AREAS OF CONTRIBUTION}

\begin{tabular}{|c|c|c|c|c|c|}
\hline \multicolumn{6}{|c|}{ Paper Category } \\
\hline$\square$ & Original Research & $\square$ & Position Paper & $\square$ & Comparative \\
\hline$\square$ & Case Study & $\square$ & Technical Briefs & $\square$ & Opinion \\
\hline$\square$ & Reviews & $\square$ & Student Paper & $\square$ & Innovation Ideas \\
\hline \multicolumn{2}{|c|}{ Type of Digital Innovation } & \multicolumn{2}{|c|}{ Industry } & \multicolumn{2}{|c|}{ Discipline } \\
\hline $\begin{array}{l}\square \\
\square \\
\square \\
\square \\
\bigotimes \\
\square \\
\square \\
\square \\
\square\end{array}$ & $\begin{array}{l}\text { Radical } \\
\text { Incremental/Enhancing } \\
\text { Disruptive } \\
\text { Breakthrough } \\
\text { Basic Research } \\
\text { Sustaining } \\
\text { Architectural } \\
\text { Component/Modular } \\
\text { Destroying }\end{array}$ & $\begin{array}{l}\square \\
\square \\
\square \\
\square \\
\square \\
\square \\
\square \\
\square \\
\bigotimes \\
\square \\
\square \\
\square \\
\square \\
\square \\
\square\end{array}$ & $\begin{array}{l}\text { Media } \\
\text { Telecom } \\
\text { Consumer Financial Services } \\
\text { Retail } \\
\text { Technology } \\
\text { Insurance } \\
\text { Consumer Products } \\
\text { Non-Profit } \\
\text { Business/Professional Services } \\
\text { Higher Education } \\
\text { K-12 Education } \\
\text { Training } \\
\text { Health Care } \\
\text { Manufacturing } \\
\text { Transportation }\end{array}$ & $\begin{array}{l}\square \\
\square \\
\square \\
\square \\
\square \\
\square \\
\square \\
\square \\
\square \\
\square \\
\square \\
\square \\
\square \\
\square \\
\square \\
\square \\
\square \\
\square \\
\square \\
\square \\
\square \\
\square\end{array}$ & $\begin{array}{l}\text { Business Technology } \\
\text { Human Resources } \\
\text { Management } \\
\text { Marketing } \\
\text { Finance } \\
\text { Accounting } \\
\text { Computer Science } \\
\text { Engineering } \\
\text { Medicine / Healthcare } \\
\text { Law } \\
\text { History } \\
\text { Philosophy } \\
\text { Religion/Theology } \\
\text { Mathematics } \\
\text { Physics } \\
\text { Digital Media } \\
\text { Astrology } \\
\text { Social Sciences } \\
\text { Art and Culture } \\
\text { Psychology/Consciousness } \\
\text { Astronomy } \\
\text { Economics }\end{array}$ \\
\hline
\end{tabular}

\begin{tabular}{lllll} 
Human Elements Addressed & & & \\
\hline$\square$ Personality Traits & $\square$ & Development & $\square$ & Mental Wellbeing \\
$\square$ Behaviour & $\square$ Environmental & $\square$ & Consciousness \\
$\square$ Cognition & $\square$ & Social & $\square$ & Physical Wellbeing \\
\hline
\end{tabular}




\section{INTRODUCTION}

Globalization is accelerating and having a growing impact on business organizations and practices (McCall and Hollenbeck 2002). As global competition continues to intensify, the Global Mindset has become increasingly important to academics and practitioners because of its criticality to long-term competitive advantage and adaptability in global markets (Harris and Moran 2004). To achieve such thresholds, there is a growing urgency that management has fostered a Global Mindset within the core fabric of their organizational structures. Global Mindset refers to "...an individual's capacity to function effectively in a bighly complex business environment across national boundaries" (Andresen and Bergholt 2017, 170). Scholars argue that Global Mindset development is related to developing a Global Leader (Kedia and Mukherji 1999). Global Leaders are defined "...as executives who are in jobs with some international scope, must effectively manage through the complex, changing, and often ambiguous global environment" (Caligiuri 2006, 219). The acute shortage of unique global talent has made influential business leaders develop an urgency to develop effective Global Leaders (PwC 2017, Bird and Mendenhall 2016, DDI Global Leadership Forecast 2014-2015, Deloitte Global Human Capital Trends 2015, DDI and the Conference Board 2015, Conger 2014, Maznevski, Stahl and Mendenhall 2013, Ghemawat 2012, IBM 2010, Cappelli 2008, Mendenhall, Osland, Bird, Oddou, Maznevski, Stevens and Stahl 2003, The Economist 2006, Mendenhall and Osland, 2002).

Here, we make an explicit assumption that a Global Leader needs a Global Mindset to be effective (e.g., Caligiuri and Tarique 2012, Javidan and Bowen 2013, Beechler and Javidan 2007). For this reason, we employ the term "Global Leadership Mindset" (GLM). Multinational Corporations (MNCs) need to have the capacity and capabilities to develop a significant number of leaders with a Global Mindset to handle the increasing diversity both globally and locally (Wiseman 2012, Javidan and Bowen 2013). Additionally, previous studies conducted by Hruby, Watkins-Matthys, and Hanke (2016), Hruby, de Melo, Samunderu, and Hartel (2018) focused on analyzing Global Leadership competencies, including the complexities of Global Mindset. Hruby et al. (2018) adopted an inductive approach by assessing 40 theoretical studies and identified inconsistencies when researchers are dealing with conceptual and theoretical development within the global mindset topic. However, Hruby et al. (2018) concluded that a Global Mindset is developed on the levels of cognitive, affective, behavioural, and cultural perspectives. Only a few studies to date describe theoretically which GLM competencies (e.g., Reiche, Bird, Mendenhall and Osland 2017) are essential for HR professionals (e.g., Goldsmith 2003, Livermore 
2011) and other business functions such as Procurement, Logistics, Finance and Controlling, Marketing \& Sales, Research \& Development, IT and Supply Chain Management. Recent (Global) HR competency models focus on the tasks and structuring the HR tasks into nine core competencies such that an HR professional must be effective in ethical practice, communication, consultation, critical evaluation, relationship management, organizational leadership, business acumen and navigation, and, importantly for this paper, global and cultural sensitivity (Society for Human Resource Management/ SHRM, 2014). No study currently exist in which GLM competencies are relevant for different Global HR positions. sons:

Our study focused on the (global) HR department, for the following rea-

a) According to the existing literature related to developing Global Leaders (e.g., Beechler and Javidan 2007, Morrison 2000, Suutari 2002), the HR function could utilize the competencies to recruit and reward qualified Global Leaders while gaining creditability to influence their organization (Muratbekova-Touron 2009).

b) Talent acquisition and embedding leadership development is a fundamental aspect of an organization's strategy since well-trained human capital can enable the organization to achieve its goals.

c) It is paramount that HR, diversity, equity, and inclusion professionals need to develop a GLM even if they work for organizations without overseas markets.

d) There is increased emphasis on (global) HR competencies development designed to increase HR's effectiveness.

e) Global HR act as a connecting link between all departments and international subsidiaries.

First, this paper aims to explain and argue on the relevance of GLM for HR leaders. It is necessary to identify the relationship between a Global Mindset on an individual level and global (leadership) competencies. Furthermore, we analyze which of these factors influence GLM development. Hence, we propose the research question: ers?"

"What are the GLM Competencies relevant for global HR lead- 
The existing global competencies model (e.g., Brake 1997, Dalton 1998, Meldrum and Atkinson 1998, Mendenhall and Osland 2002, Bird 2018) identify the relevance of transnational competencies. It is necessary to highlight a GLM model for the Global HR function (SHRM 2016, Ulrich et al. 2012) as a central role in supporting different managers and worldwide locations. This remainder of the paper is organized as follows: a literature review, methodology, findings and discussion section, and a conclusion with the study's contributions, limitations, managerial implications, and future research.

\section{LITERATURE REVIEW}

A common denominator of the existing frameworks on GLM competencies assumes that leaders must possess cognitive abilities to succeed in a complex environment. One component frequently featured is the Global Mindset, defined as "...a highly complex cognitive structure characterized by an openness to and articulation of multiple cultural and strategic realities on both global and local levels, and the cognitive ability to mediate and integrate across this multiplicity" (Levy, Beechler, Taylor and Boyacigiller, 2007, 27). The construct of Global Mindset is of complex nature and multifaceted and has received much attention in the literature (Hruby et al. 2018, Levy et al. 2007). Leaders need to have an awareness of issues and trends from a Global Mindset perspective in order to succeed in the competitive markets. (Mendenhall 2018, Mendenhall et al. 2016, Osland 2018, Goldsmith, Greenburg, Robertson and Hu-Chan 2003). Global Mindset is a driver for success, influencing MNCs (Gaffney, Cooper, Kedia, Clampit, and Mohamed 2012) and SMEs (e.g., Koh et al. 2014, Lazaris and Freeman 2018, Felício, Meiduté and Kyvik 2016, Felício, Caldeirinha and Ribeiro-Navarrete 2015, Felício, Caldeirinha and Rodrigues 2012, Felício, Calderinha, Rodrigues and Kyvik 2013, Kyvik, Saris, Bonet, Félicio, 2013, Miocevic, and Crnjak-Karanovic 2012, Kyvik 2017, Kyvik 2018). Global Mindset increases leaders' capacity to plan and coordinate. The high level of cognitive complexity manifests the ability to lead, communicate, and collaborate with people, groups, and organizations from various cultures (Konyu-Fogel, 2011). To demonstrate the "connectivity among all aspects of research," Hruby et al. (2018) developed a conceptual framework displaying Global Mindset as the cognitive component to Global Leadership construction. Furthermore, it shows overlapping dimensions (traits, predisposition, knowledge, skills, Abilities, and Global Leadership) as a prerequisite for developing both Global Leadership and Global Mindset. In Figure 1, illustrates the relationships. 


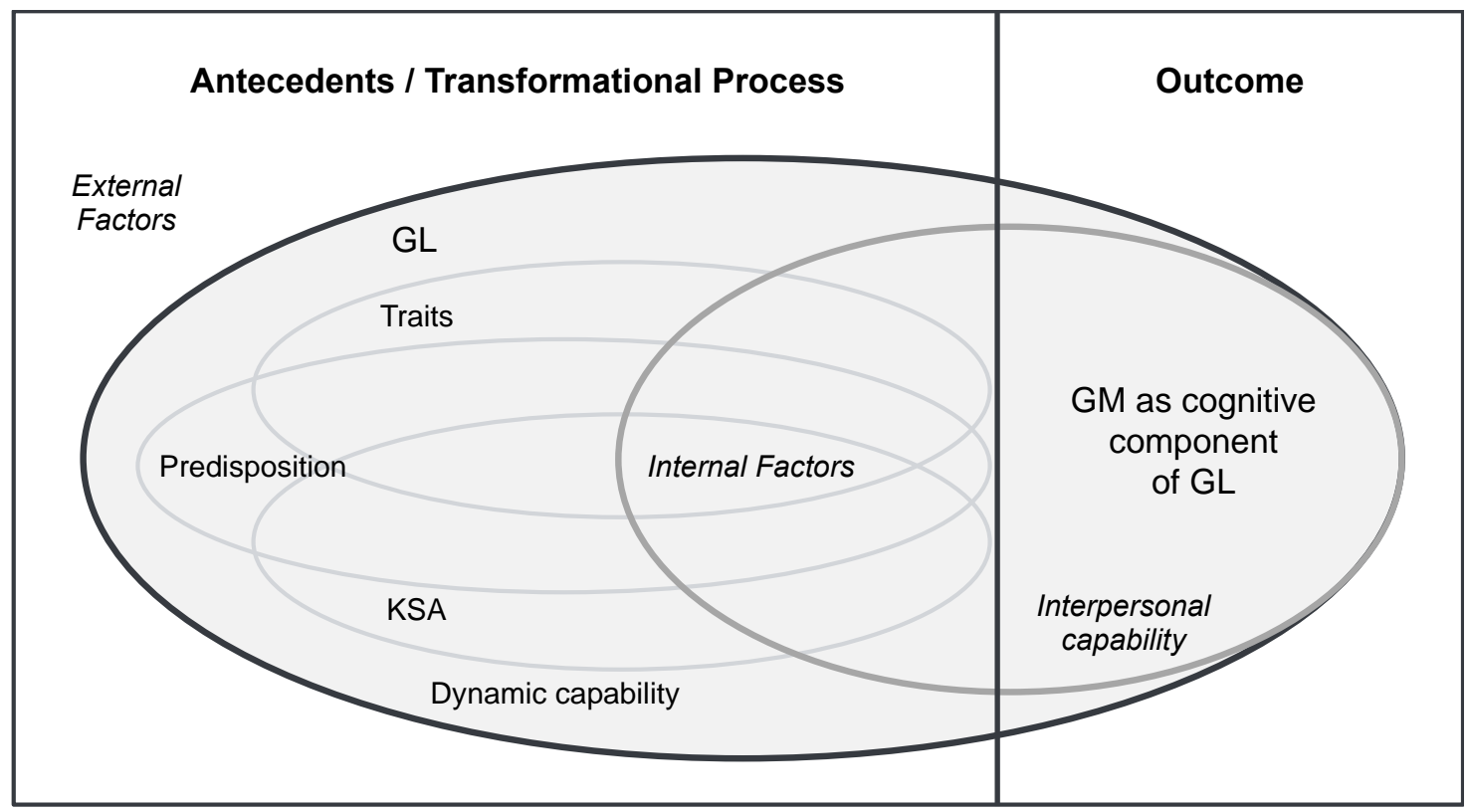

Figure 1: GM Framework as Cognitive Component of the Global Leadership Construction (Hruby et al., 2018)

\section{CHARACTERISTICS OF A GLOBAL MINDSET AT THE INDIVIDUAL LEVEL}

An individual Global Mindset is linked to a Global Leader because they set the company's strategic direction and influence the globalization of their business and human resource (Adler and Bartholomew 1992, Aycan 2001, Conner 2000, McCall and Hollenbeck 2002). Caligiuri and Tarique (2014) emphasize the importance of individual accelerators of GLM development, which can be developed through either international assignment experiences or cross-cultural experiential opportunities. Javidan and Walker (2012) state that a Global Leader's qualities are determinants in mastering situations that translate to business and management roles. A Global Leader possesses different qualities that are applied to solve global problems (Lovvorn and Chen 2011) and should be equipped with superior communication skills.

\section{THE ROLE OF GLOBAL MINDSET IN THE CONTEXT OF GLOBAL LEADERSHIP}

A Global Mindset's central value is closely associated with an international work experience, openness to cross-cultural interactions, and leadership ability, such as curiosity about the world and conflict management. A Global Leader is defined as individuals "...who influence a range of internal and external constituents from multiple national cultures and jurisdictions in a context characterized by significant levels of task and relationship complexity" (Reiche, Bird, Mendenhall, and Osland 2017, 556). MNCs need managers with a Global Mindset to handle the increasing 
diversity globally and locally (Javidan and Bowen 2013). Scholars have focused on the relationship between Global Mindset and Global Leadership in order to understand the ubiquity of a Global Mindset and its functions. Two central schools of thought can be identified: (1) Global Mindset is an antecedent of Global Leadership (Dekker 2016, Levy et al. 2007, Mendenhall 2018, Reiche et al. 2017), meaning it is the elementary requirement, which Global Leadership competencies build upon, and (2). Global Mindset is a sine qua non component of Global Leadership and its competencies (Hruby et al. 2018, 99). Global Mindset has been characterized as an indispensable component of Global Leadership. For example, Reiche et al. (2017) contend that Global Mindset is the intrapersonal capability required for Global Leadership, the external process of taking influence (Reiche et al. 2017, 557; Hruby et al. 2018). In the pyramid model of Global Leadership, a Global Mindset is listed among the attitudes and orientations central to Global Leadership (Bird and Osland 2004, Osland 2018). Therefore, the development of a Global Mindset is an ongoing process that involves traits, personality, and behaviour (e.g., Gupta et al. 2008, 138).

\section{GLOBAL LEADERSHIP COMPETENCIES}

Based on the plethora of literature discussing leadership, a wide range of studies have focused on developing traits, skills, competencies, and behaviours that Global Leaders need to exhibit in order to succeed. Studies by Wills and Barham (1994), Brake (1997), Dalton (1998), Bird and Osland (2004), Jokinen (2005), Osland et al., (2006), Mumford, Campion, and Morgeson (2007), Mendenhall and Osland (2002), Jokinen (2005), Kim and McLean (2015), Cumberland et al. (2016), Bird (2018), Mendenhall, Weber, Arnadottir, and Oddou (2017), Mendenhall, Burke-Smalley, Arnardottir, Oddou and Osland (2020), among others have introduced frameworks elaborating on the global competencies required to master leadership in a global setting. More recently, Bohas et al. $(2021,24)$ pointed out that global leadership and global mindset development are interdependent, based on specific skills, self-reflection, and experiential learning, and transformational processes (Caligiuri and Tarique 2012, Henson 2016). Cumberland et al. (2016) identify global leadership competencies such as cognitive complexity, behavioural complexity, cross-cultural skills, business savvy, and the ability to manage uncertainty, developed through international assignments (Osland 2001). Osland et al. (2006), Kim and McLean (2015) build an integrative framework for global leadership competency and provide different analysis levels and dimensions. Kim and McLean (2015) divide the levels into core traits, personal character, and abilities. On the other continuum are dimensions such as intercultural, interpersonal, global 
business, and global organizational competencies. According to Mendenhall et al. (2020, 331), a straightforward classification of global leadership competencies can be into global business competencies and intercultural competencies. The latter is an antecedent for global business competencies. There is substantial literature that discusses leadership competencies but it is unclear which global competencies are relevant for global HR.

\section{IDENTIFYING TALENT FOR GLM DEVELOPMENT}

In recent years, decisions concerning which employees belong in the talent pool have received considerable attention (Björkman et al., 2013; Gelens et al., 2014; McDonnell et al., 2016). Organizations tend to rely on multiple experiences, encounters, decisions, and challenges (Osland \& Bird, 2008) to prepare people to take on Global Leadership roles and enhance the growth and development of individuals already in Global Leadership roles. In other words, there is a need to search for individuals who can effectively manage the complex, challenging, changing, and often-ambiguous global environment (Caligiuri \& Bonache 2016). When staffing a Global Leader position, a company has two options: selecting (either from outside or from inside the organization) the right person or developing the required abilities for improved performance (Caligiuri 2006; Spencer 1993). Generally speaking, having the right people in the right position at the right time is critical to the long-term performance of any firm, especially for international-oriented. Identifying potential candidates requires the multi-faceted capabilities of managers in MNCs. In this regard, MNCs primary challenge is the same as those faced by local companies: how to identify, attract, and obtain the desired types of talent in a manner that is efficient, fair, and offers an acceptable economic return on costs. However, because of the changing global business environment and tight labor markets, a multinational company cannot always select or recruit existing leaders. It means HR professionals must develop their current employees to prepare them for future Global Leadership positions.

Thus, there are different ways of identifying and selecting potentials within organizations. The easiest way is to rely on managers' judgment regarding employees' performance and potential. Potential impediments of this approach may be that these judgments may be tainted by personal relationships or previous manager experiences (Murphy \& Cleveland, 1995). On the other hand, top executives must consider the full range of leadership criteria, such as traits, characteristics, and experience in order to fulfill their global leadership pipeline. Therefore, many companies are struggling with a leadership shortage. The development of Global Leadership competence is an urgent requirement for an organization to become more globally competent. Talent development systems 
for developing global leaders need to be based on the notion that one-size does not fit all. Current evidence suggests that many companies use an ad hoc approach to developing talent (McDonnell, Lamare, Gunnigle \& Lavella, 2010) rather than a systemic approach for developing talent. Thus, organizations should implement a specialized recruitment strategy to identify the high potential leaders.

\section{(GLOBAL) HR COMPETENCY MODELS}

Most of the HR competency literature links HR competencies (knowledge, skills, and abilities of HR required of HR professionals) to the value-added approach suggested by Ulrich and the Strategic Human Resource Management (SHRM) HR Competency Model. HR competency is a cluster of characteristics contributing to HR professionals' effective performance that helps an organization successfully implement its business strategies in a competitive market (Long and Ismail, 2008). Eichinger and Lobardo (1990) identified HR competencies in leadership areas, including business knowledge, personal management, job skills, achievement-directed assertiveness, interpersonal effectiveness, cognitive complexity, and agility. In an earlier study, Ulrich and Brockbank (2005) differentiated HR competencies into strategic and functional categories. In addition to these role-specific HR competencies, there are a small set of core/generic competencies that are shared by multiple HR roles (Blancero et al. 1996, Yeung et al. 1996). Lo et al. (2013) show that HR competencies are categorized into strategic focus and drive, leadership and relationship building, business awareness, systems and technology, input and support, HR acumen and self-belief, and social factors. Besides emphasizing generic HR competencies, some scholars have claimed that HR competencies are "role-specific" (Yeung et al. 1996, Blancero et al. 1996).

Yeung et al. (1996) developed a small set of core competencies for various HR roles such as effective communication, credibility, and integrity, negotiation and conflict resolution, systematic perspective, business acumen, customer orientation as well as some role-specific competencies, namely strategic HR competencies linked to leadership HR roles and functional HR competencies for consultation and specialist HR expertise roles. However, less scientific emphasis is illustrated on the analysis of Global HR competency models and the specific Global HR roles (Ulrich et al. 2012). Within the SHRM HR Competency model (http://www.shrm.org/HRCompetencies/Pages/defaultaspx.) consisting of nine competencies, only one competency explicitly focuses on the global and cultural effectiveness and include: global perspective, openness to various perspectives, tolerance for ambiguity, openness to experience, diversity perspective, 
adaptability, Empathy, Adaptability and Cultural Awareness and Respect (Cohen 2015, 208). Kohont and Brewster (2014) found in their empirical study that the HR roles and related competencies varied from a national to an international company. The relevant competencies in a MNC HR department are "orientation to people and conflict resolution" as elementary competencies needed in all stages of internationalization. According to CEOs and expatriates observed in the sample, the key competence within MNCs is strategic thinking, cultural sensitivity, openness to change, and a comprehensive understanding of the international environment and business processes.

\section{METHOdology AND DATA COLlECTION}

Based on the evaluation of the literature presented above, our study attempts to assess competencies of global HR functional roles. We identify 26 functional HR roles and 11 functional layers for the study by drawing a perspective on at least 11 key competencies (measures) related to each function. McClelland's (1973) logic on assessing performance provides a robust baseline for evaluating GLM competencies with criterion sampling. For our study, 75 competencies are identified and a ranking order conducted to ensure which GLM competencies provided a fit for a particular global HR function. We then classify GLM competencies into six categories: (1) cognitive, (2) cultural, (3) behavioral, (4) emotional/affective, (5) self-management, and (6) Global Leadership skills. Each category contains at least eleven competencies relevant for a Global Leadership position (See Table 1). Our empirical research classified global competencies into six levels: cognitive, affective, behavioral, cultural, self-management, and global leadership skills. Different authors (Cumberland et al. (2016); Kim and McLean (2015); Bird and Stevens, 2013; Osland et al. 2006; Jokinen (2005)) classifies global competencies but we shed light on classifying the global competencies directly related to global mindset development (Hruby et al., 2018). By analyzing the aforementioned literature, we have observed a lack of global competencies relevant to different business functions and positions. We believe that the classification into six levels instead of listing these global competencies brings more clarity on which levels are most relevant in training and developing global leaders. We extend the four levels mentioned by Hruby et al. (2018) with the self-management and global leadership skills because global leaders have more cognitive mindset and characteristics and tasks highlighted by Huesing (2016), Huesing and Ludema (2017). 
Table 1: Global Leadership Mindset Competencies

\begin{tabular}{|c|c|c|c|c|c|c|}
\hline No. & $\begin{array}{c}\text { COGNITIVE } \\
\text { COMPETENCIES }\end{array}$ & $\begin{array}{l}\text { CULTURAL } \\
\text { COMPETENCIES }\end{array}$ & $\begin{array}{l}\text { BEHAVIORAL } \\
\text { COMPETENCIES }\end{array}$ & $\begin{array}{c}\text { EMOTIONAL/AFFECTIVE } \\
\text { COMPETENCIES }\end{array}$ & $\begin{array}{l}\text { SELF-MANAGEMENT } \\
\text { SKILLS }\end{array}$ & $\begin{array}{c}\text { GLOBAL LEADERSHIP } \\
\text { SKILLS }\end{array}$ \\
\hline 1 & Cognitive Complexity & InterculturaI Sensitivity & Interpersonal Engagement & Open-M indedness & Self-Awareness & $\begin{array}{l}\text { Leading Remote/ Leading } \\
\text { Global Virtual Teams }\end{array}$ \\
\hline 2 & Cognitive F lexibility & $\begin{array}{l}\text { Awareness And Knowledge of } \\
\text { Cultural Differences }\end{array}$ & $\begin{array}{c}\text { Social Competence/Social } \\
\text { Capital }\end{array}$ & Emotional Intelligence & Self-Confidence & Building Global Business Teams \\
\hline 3 & Glo bal Business Knowledge & $\begin{array}{l}\text { Intercultural Communication } \\
\text { Skills }\end{array}$ & Conflid Management & Emotional Empathy & Self-Reflection & Collaboration In Global Teams \\
\hline 4 & Meta-Cognitive Awareness & $\begin{array}{l}\text { Acceptance/ Respectfulness/ } \\
\text { Tolerance } 0 \text { f Others }\end{array}$ & Networking Skills & Humility/Humbleness & Self-Regulation & Visioning/Providing Direction \\
\hline 5 & Duality 0 f Thinking & Cognitive Cultural Intelligence & Integrity & Curiosity & Self-Identity & Empowering Others \\
\hline 6 & Learning Agility & Behavioral Cultural Intelligence & $\begin{array}{l}\text { Understanding Different } \\
\text { Negotiation Styles }\end{array}$ & Non-Judgem entalness & Positivity And 0ptim ism & $\begin{array}{l}\text { Rewarding And Giving } \\
\text { Feedback }\end{array}$ \\
\hline 7 & Cosmopolitanism & $\begin{array}{l}\text { Motivational Cultural } \\
\text { Intelligence }\end{array}$ & Step Out OfThe Comfort Zone & M anaging Uncertainty & Emotional Resilience & Persistence \\
\hline 8 & Complex Problem-Solving Skills & Intercultural Interaction Skills & Building T rust & Risk-Taking & Hardiness & Leading Change \\
\hline 9 & $\begin{array}{c}\text { Willingness To Understand } \\
\text { Others }\end{array}$ & Cultural Agility & Behavioral Flexibility & Patience & Stress Management & Global Talent Management \\
\hline 10 & Language Pro ficiency & $\begin{array}{l}\text { Cross-Cultural Competencies } \\
\text { And Skills }\end{array}$ & Cross-Border M obility & Appreciation Of Others & Energy $M$ anagement & Fostering Innovation \\
\hline 11 & $\begin{array}{l}\text { Strategic And Critical Thinking } \\
\text { Skills }\end{array}$ & Cross-Cultural Effectiveness & $\begin{array}{l}\text { Listening, Reflecting And } \\
\text { Observation Skills }\end{array}$ & Tolerance Of Ambiguity & Work-Life Balance & Influencing Stakeholders \\
\hline 12 & & Intercultural Adaptability & Intercultural Adaptation & & Self-E fficacy & $\begin{array}{c}\text { Ethical And Responsible/ Vale } \\
\text { Based Global Leader }\end{array}$ \\
\hline 13 & & & & & & Perspective Taking \\
\hline 14 & & & & & & Diplomacy \\
\hline 15 & & & & & & Customer Orientation \\
\hline 16 & & & & & & M otivating And Engaging Skills \\
\hline 17 & & & & & & Coaching And M entoring Skills \\
\hline
\end{tabular}

The dataset was from Germany companies focusing on the Global HR departments within different industry settings. The companies' choice were MNCs and "German Mittelstand" mid-sized companies and the sampling framework required these individuals to be responsible for Global HR. Overall, LinkedIn was used as a platform to extrapolate data, with a link for a survey that registered 4020 senior HR leaders as potential respondents. The response rate showed a result of 256 completed the survey. A web-based survey using Questback EFS Fall 2019 was used to analyze the responses. This approach allowed the survey to gain a broader and diverse picture of global HR leaders' sample. The study's level of response indicates an $83.59 \%$ response rate from either individual with a managerial or executive role within the global HR function of their organization. The 256 participants surveyed used a random sampling method and represented different roles within HR function (See Table 2). 
Table 2: Global Mindset Development and data on participants' positions

\begin{tabular}{|c|c|c|}
\hline Functional Role & $\begin{array}{l}\text { Number of } \\
\text { respondents }\end{array}$ & $\begin{array}{c}\text { Percentage } \\
(\%)\end{array}$ \\
\hline CHRO & 23 & $7.01 \%$ \\
\hline Global Talent Manager & 5 & $1.52 \%$ \\
\hline Head of Global HR & 32 & $9.76 \%$ \\
\hline VP or Executive VP Human Resources & 43 & $13.11 \%$ \\
\hline Human Resource Development Spezialist & 12 & $3.66 \%$ \\
\hline $\begin{array}{l}\text { Head of Global Learning/ Head of Global Develop- } \\
\text { ment/ Head of Global Training/ Head of Vocational } \\
\text { Training }\end{array}$ & 16 & $4.88 \%$ \\
\hline $\begin{array}{l}\text { VP Global Learning or VP Global Training or VP Global } \\
\text { Training }\end{array}$ & 1 & $0.30 \%$ \\
\hline HR EMEA & 4 & $1.22 \%$ \\
\hline Global HR Business Partner & 18 & $5.49 \%$ \\
\hline Head of Global HR Business Partner & 3 & $0.91 \%$ \\
\hline HR Business Partner & 20 & $6.10 \%$ \\
\hline Head of HR Business Partner & 6 & $1.83 \%$ \\
\hline Director HR & 43 & $13.11 \%$ \\
\hline Head of People or Head of Global People & 9 & $2.74 \%$ \\
\hline Senior Expert Human Resource Development & 15 & $4.57 \%$ \\
\hline Head of Corporate Program/ Program Director & 4 & $1.22 \%$ \\
\hline Head of HR Development & 7 & $2.13 \%$ \\
\hline HR Consultant & 20 & $6.10 \%$ \\
\hline VP People/ VP Global People & 2 & $0.61 \%$ \\
\hline Global Mobility & 8 & $2.44 \%$ \\
\hline HR Generalist & 8 & $2.44 \%$ \\
\hline HR IT & 6 & $1.83 \%$ \\
\hline HR Reward / HR Compensation & 2 & $0.61 \%$ \\
\hline HR Controlling & 1 & $0.30 \%$ \\
\hline HR Employer Branding & 2 & $0.61 \%$ \\
\hline
\end{tabular}




\begin{tabular}{lcc}
\hline HR Recruiting/ global Recruiting & 4 & $1.22 \%$ \\
I prefer not to answer (non-identified role) & 14 & $4.27 \%$ \\
Total & 328 & \\
Average & 10.77 & \\
\hline
\end{tabular}

Table 3 displays the participants' demographic information. The gender splitup consisted of $55.8 \%$ male and $42.11 \%$ female, with only $2.02 \%$ not indicating their gender. The age distribution also indicated that the age bracket of 51-55year-old had the highest percentage rate $(22.67 \%)$ in terms of global HR functions and the 66-72-year-old with the lowest percentage of $0.40 \%$. The diversity of industries allowed our investigation to capture the fundamental skills required to perform a specific function, irrespective of the industry setting. Although the sample used in this study cannot represent all global HR professionals by no means, the participants provided an excellent variation for our study to examine the scale of competencies required to reflect GLM development skills. Manufacturing recorded the highest value of participants with a $26.32 \%$ percentage rate, and Public administration and defense (0.40\%), Agriculture, forestry, and fishing (1.21\%) reflected the lowest percentage rate. Water supply, sewerage, waste management, remediation activities, and construction all registered $0 \%$ percentage rates (See Table 3).

Table 3: Demographic information and industry of the participants

\begin{tabular}{llcc}
\hline Variables & Values & Frequency & Percentage (\%) \\
\hline \multirow{2}{*}{ Gender } & Male & 138 & $55.87 \%$ \\
& Female & 104 & $42.11 \%$ \\
& Prefer not to answer & 5 & $2.02 \%$ \\
\hline Age & Under 25 & 2 & $0.81 \%$ \\
& $25-30$ & 9 & $3.64 \%$ \\
& $31-35$ & 15 & $6.07 \%$ \\
& $36-40$ & 28 & $11.34 \%$ \\
& $41-45$ & 40 & $16.19 \%$ \\
& $46-50$ & 49 & $19.84 \%$ \\
& $51-55$ & 56 & $22.67 \%$ \\
\hline
\end{tabular}

A New Era of Global HR Competency Model 


\begin{tabular}{|c|c|c|c|}
\hline & $56-60$ & 29 & $11.74 \%$ \\
\hline & $60-65$ & 12 & $4.86 \%$ \\
\hline & $66-72$ & 1 & $0.40 \%$ \\
\hline & No answer & 6 & $2.43 \%$ \\
\hline & Agriculture, forestry and fishing & 3 & $1.21 \%$ \\
\hline & Mining and quarrying & 4 & $1.62 \%$ \\
\hline & Manufacturing & 65 & $26.32 \%$ \\
\hline & $\begin{array}{l}\text { Electricity, gas, steam and air condition- } \\
\text { ing supply }\end{array}$ & 5 & $2.02 \%$ \\
\hline & $\begin{array}{l}\text { Water supply; sewerage, waste manage- } \\
\text { ment and remediation activities }\end{array}$ & 0 & $0.00 \%$ \\
\hline Industry & Construction & 0 & $0.00 \%$ \\
\hline & $\begin{array}{l}\text { Wholesale and retail trade; repair of mo- } \\
\text { tor vehicles and motorcycles }\end{array}$ & 8 & $3.24 \%$ \\
\hline & Transport and storage & 11 & $4.45 \%$ \\
\hline & $\begin{array}{l}\text { Accommodation and food service activi- } \\
\text { ties }\end{array}$ & 4 & $1.62 \%$ \\
\hline & Information and communication & 16 & $6.48 \%$ \\
\hline & Financial and insurance activities & 15 & $6.07 \%$ \\
\hline & Real estate activities & 3 & $1.21 \%$ \\
\hline & $\begin{array}{l}\text { Professional, scientific and technical ac- } \\
\text { tivities } \\
\text { Administrative and support service activi- } \\
\text { ties }\end{array}$ & 24 & $9.72 \%$ \\
\hline & Public administration and defense & 1 & $0.40 \%$ \\
\hline & Education & 18 & $7.29 \%$ \\
\hline & Human health and social work activities & 10 & $405 \%$ \\
\hline & Arts, entertainment and recreation & 0 & $0.00 \%$ \\
\hline & $\begin{array}{l}\text { Private households as employers; undif- } \\
\text { ferentiated goods- and services-producing } \\
\text { activities of households for own use }\end{array}$ & 0 & $0.00 \%$ \\
\hline
\end{tabular}




\begin{tabular}{|c|c|c|c|}
\hline & $\begin{array}{l}\text { Activities of extraterritorial organizations } \\
\text { and bodies }\end{array}$ & 1 & $0,40 \%$ \\
\hline & Other service activities & 56 & $22.67 \%$ \\
\hline \multirow{14}{*}{$\begin{array}{l}\text { Employee } \\
\text { Size }\end{array}$} & Up to 9 & 20 & $8.23 \%$ \\
\hline & $10-49$ & 13 & $5.35 \%$ \\
\hline & $50-99$ & 5 & $2.06 \%$ \\
\hline & $100-249$ & 14 & $5.76 \%$ \\
\hline & $250-499$ & 8 & $3.29 \%$ \\
\hline & $500-999$ & 18 & $7.41 \%$ \\
\hline & $1000-2499$ & 25 & $10.29 \%$ \\
\hline & $2500-4999$ & 25 & $10.29 \%$ \\
\hline & 5000-9999 & 27 & $11.11 \%$ \\
\hline & 10000-19999 & 19 & $7.82 \%$ \\
\hline & 20000-49999 & 13 & $5.35 \%$ \\
\hline & 50000-199999 & 44 & $18.11 \%$ \\
\hline & over 200000 & 9 & $3.70 \%$ \\
\hline & I prefer not to answer & 3 & $1.23 \%$ \\
\hline \multirow{6}{*}{$\begin{array}{l}\text { International/ } \\
\text { Global } \\
\text { Subsidiaries }\end{array}$} & $0-5$ & 50 & $22.32 \%$ \\
\hline & $6-10$ & 30 & $13.39 \%$ \\
\hline & $11-20$ & 26 & $11.61 \%$ \\
\hline & $21-50$ & 37 & $16.52 \%$ \\
\hline & $51-100$ & 34 & $15.18 \%$ \\
\hline & more than 100 & 47 & $20.98 \%$ \\
\hline
\end{tabular}

Additionally, we examined how employee size influenced HR functions. Notably, companies with high employee sizes ranging from 500 had a significant percentage rate, and international companies with global subsidiaries displayed the highest percentage rate of $22.32 \%$ with a frequency of 50 participants. 


\section{ANALYSIS AND RESULTS}

Analyzing GLM competencies requires researchers to examine multiple factors to validate the level of competencies leaders may have within their HR functional roles. Since there is no "one size fits all" competency model, adopting a factor model analysis does shed some light on the underlining factors that govern GLM competencies. Below is a conceptual framework of a Common Factor Model (Figure 2). The model proposes that each of the observed responses (measure 1 to measure 5) is influenced partially by common underlying factors (factor $1 \ldots 2 \ldots 3 \ldots \mathrm{n})$ and partially by unique underlying factors (E1...E2...En). The strength of the link found between each factor and measure tends to vary, indicating that some factors influence some measures more than the others do. For this reason, the model resonates with the ability to understand multiple factors that could influence an individual's GLM competencies and metacompetencies. Our results revealed findings with multiple elements that define leadership competencies and prescribed Global HR functions (See Figure 2).

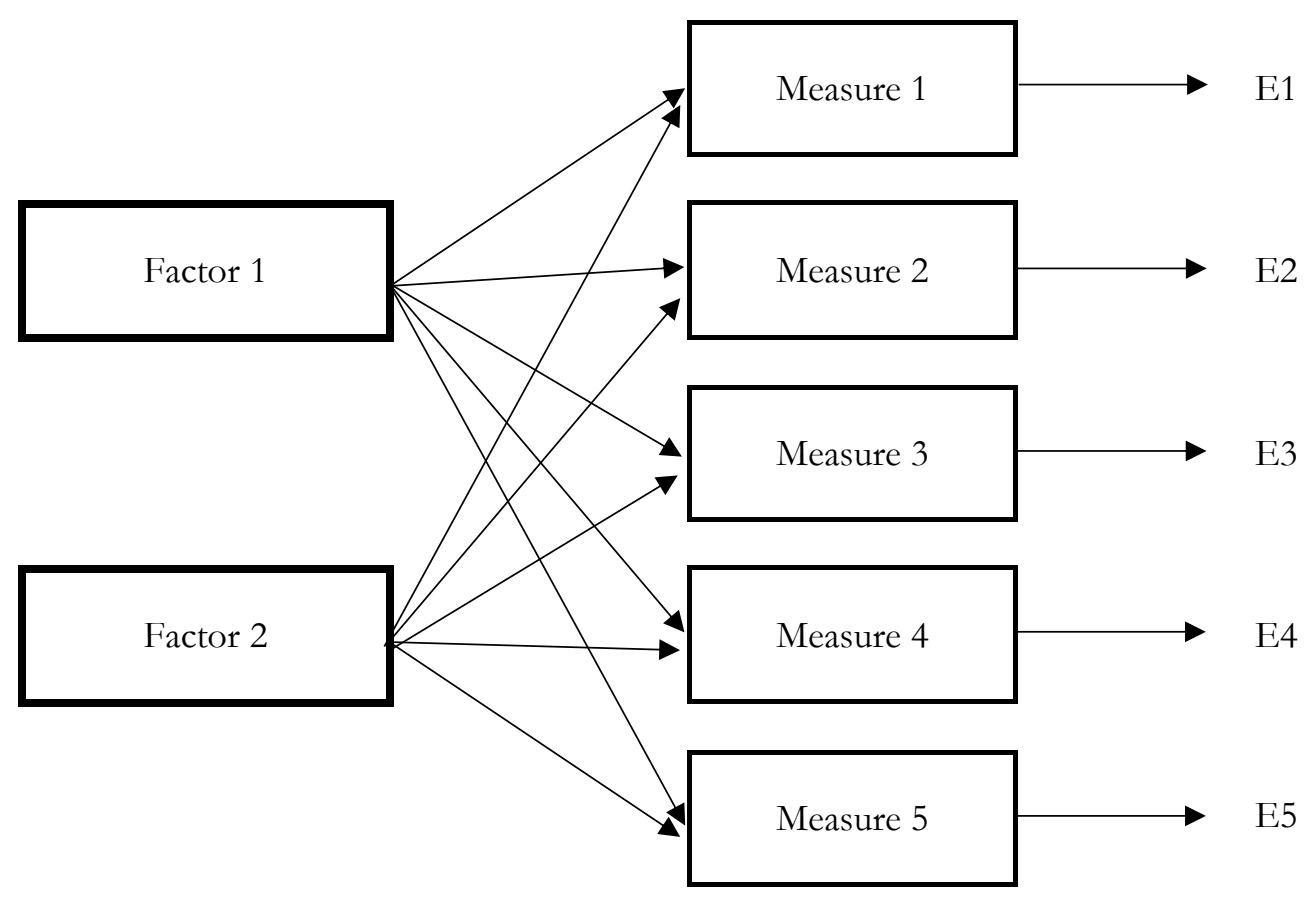

Figure 2: Conceptual framework of the Common Factor Model

We firstly analyzed the theoretical framework of Global Mindset and then examined the sample study's responses and adopted Exploratory Factor Analysis (EFA) to explore the essential components of global competencies of global HR professionals. We employed EFA in SPSS 23 to explore the essential com 
ponents of global competencies. Before the extraction of factors, we conducted a 2-tests analysis to assess the suitability of respondent data for factor analysis. In order to validate that the dataset was suitable for EFA, we also conducted the Kaiser-Mayer-Olkin (KMO) test for validating sampling adequacy and Bartlett's test of sphericity (level of significance $(\mathrm{p}<.05)$ The KMO index has a range from 0 to 1 with 0.50 considered suitable factor analysis and in our test, we had an index of 0.51 . Adopting factor analysis has allowed us to reduce the number of variables (75 skills) into a smaller set of variables (11 skills) because we could establish underlining dimensions between measured variables and latent constructs, therefore allowing the formation and refinement of Global Competency theory. The KMO value and Bartlett's test were significant ( $\mathrm{p} \leq$ .001 ), and this indicated that the data were sufficient and favorable for conducting EFA. Since our study focused on implicit testing methods, future studies will focus on explicitly amplifying the topic under investigation. The first observation of our study focused on cognitive competencies, and the 11 measures were analyzed on the respective sample in order of importance. Table 4 shows the cognitive competencies with "willingness to understand to understand others" having the highest-ranking score of $62.3 \%$, and other competencies such as "complex problem solving" and "learning agility" were also ranked high.

Table 4: Cognitive Competencies

\begin{tabular}{lcccccc}
\hline $\begin{array}{l}\text { Cognitive } \\
\text { Competencies }\end{array}$ & $\begin{array}{c}\text { Not im- } \\
\text { portant }\end{array}$ & $\begin{array}{c}\text { Little im- } \\
\text { portant }\end{array}$ & $\begin{array}{c}\text { Average } \\
\text { important }\end{array}$ & $\begin{array}{c}\text { Very im- } \\
\text { portant }\end{array}$ & $\begin{array}{c}\text { Absolutely } \\
\text { important }\end{array}$ & $\begin{array}{c}\text { I don't } \\
\text { know }\end{array}$ \\
\hline $\begin{array}{l}\text { Cognitive } \\
\text { Complexity }\end{array}$ & $1.12 \%$ & $0.37 \%$ & $5.60 \%$ & $38.81 \%$ & $53.73 \%$ & $0.37 \%$ \\
Cognitive & $(3)$ & $(1)$ & $(15)$ & $(104)$ & $(144)$ & $(1)$ \\
Flexibility & $1.12 \%$ & $1.12 \%$ & $9.70 \%$ & $43.66 \%$ & $44.03 \%$ & $0.37 \%$ \\
Global & $(3)$ & $(3)$ & $(26)$ & $(117)$ & $(118)$ & $(1)$ \\
Business & $0.37 \%$ & $5.60 \%$ & $14.93 \%$ & $48.51 \%$ & $30.60 \%$ & $0.00 \%$ \\
Knowledge & $(1)$ & $(15)$ & $(40)$ & $(130)$ & $(82)$ & $(0)$ \\
Meta- & $1.12 \%$ & $2.62 \%$ & $21.35 \%$ & $47.19 \%$ & $26.59 \%$ & $1.12 \%$ \\
Cognitive & $(3)$ & $(7)$ & $(57)$ & $(126)$ & $(71)$ & $(3)$ \\
Awareness & & & & & & \\
Duality of & $1.12 \%$ & $4.48 \%$ & $16.79 \%$ & $38.06 \%$ & $38.81 \%$ & $0.75 \%$ \\
Thinking & $(3)$ & $(12)$ & $(45)$ & $(102)$ & $(104)$ & $(2)$ \\
& & & & & & \\
Learning & $0.37 \%$ & $0.37 \%$ & $8.58 \%$ & $37.31 \%$ & $52.61 \%$ & $0.75 \%$ \\
Agility & $(1)$ & $(1)$ & $(23)$ & $(100)$ & $(141)$ & $(2)$ \\
& & & & & & \\
\hline
\end{tabular}




\begin{tabular}{|c|c|c|c|c|c|c|}
\hline $\begin{array}{l}\text { Cosmo- } \\
\text { Politanism }\end{array}$ & $\begin{array}{c}1.87 \% \\
(5)\end{array}$ & $\begin{array}{l}6.34 \% \\
(17)\end{array}$ & $\begin{array}{c}26.87 \% \\
(72)\end{array}$ & $\begin{array}{c}44.40 \% \\
(119)\end{array}$ & $\begin{array}{c}20.52 \% \\
\quad(55)\end{array}$ & $\begin{array}{c}0.00 \% \\
\quad(0)\end{array}$ \\
\hline $\begin{array}{l}\text { Complex } \\
\text { Problem- } \\
\text { Solving Skill }\end{array}$ & $\begin{array}{l}0.39 \% \\
\quad(1)\end{array}$ & $\begin{array}{c}1.18 \% \\
(3)\end{array}$ & $\begin{array}{c}5.49 \% \\
(14)\end{array}$ & $\begin{array}{c}39.61 \% \\
(101)\end{array}$ & $\begin{array}{c}52.55 \% \\
(134)\end{array}$ & $\begin{array}{l}0.78 \% \\
\quad(2)\end{array}$ \\
\hline $\begin{array}{l}\text { Willingness to } \\
\text { Understand } \\
\text { Others }\end{array}$ & $\begin{array}{l}0.37 \% \\
\quad(1)\end{array}$ & $\begin{array}{l}0.00 \% \\
\quad(0)\end{array}$ & $\begin{array}{c}4.85 \% \\
(13)\end{array}$ & $\begin{array}{c}31.34 \% \\
(84)\end{array}$ & $\begin{array}{c}62.31 \% \\
(167)\end{array}$ & $\begin{array}{c}1.12 \% \\
\text { (3) }\end{array}$ \\
\hline $\begin{array}{l}\text { Language } \\
\text { Proficiency }\end{array}$ & $\begin{array}{c}3.73 \% \\
\quad(10)\end{array}$ & $\begin{array}{c}3.73 \% \\
\quad(10)\end{array}$ & $\begin{array}{c}18.66 \% \\
(50)\end{array}$ & $\begin{array}{c}37.31 \% \\
(100)\end{array}$ & $\begin{array}{c}36.57 \% \\
(98)\end{array}$ & $\begin{array}{c}0.00 \% \\
(0)\end{array}$ \\
\hline $\begin{array}{l}\text { Strategic and } \\
\text { Critical } \\
\text { Thinking } \\
\text { Skills }\end{array}$ & $\begin{array}{l}0.75 \% \\
\quad(2)\end{array}$ & $\begin{array}{l}0.38 \% \\
\quad(1)\end{array}$ & $\begin{array}{c}8.30 \% \\
(22)\end{array}$ & $\begin{array}{c}43.40 \% \\
(115)\end{array}$ & $\begin{array}{c}46.04 \% \\
(122)\end{array}$ & $\begin{array}{c}1.13 \% \\
(3)\end{array}$ \\
\hline
\end{tabular}

In Table 5, cultural GLM competencies were assessed and the results from the survey are presented below. In terms of absolute importance, "acceptance/respectfulness and tolerance of others" score was very high, with $51.49 \%$.

Table 5: Cultural competencies

\begin{tabular}{|c|c|c|c|c|c|c|}
\hline $\begin{array}{l}\text { Cultural } \\
\text { Competencies }\end{array}$ & $\begin{array}{l}\text { Not im- } \\
\text { portant }\end{array}$ & $\begin{array}{l}\text { Little im- } \\
\text { portant }\end{array}$ & $\begin{array}{c}\text { Average } \\
\text { important }\end{array}$ & $\begin{array}{l}\text { Very im- } \\
\text { portant }\end{array}$ & $\begin{array}{c}\text { Absolutely } \\
\text { important }\end{array}$ & $\begin{array}{l}\text { I don't } \\
\text { know }\end{array}$ \\
\hline $\begin{array}{l}\text { Inter-Cultural } \\
\text { Sensitivity }\end{array}$ & $\begin{array}{c}1.50 \% \\
\text { (4) }\end{array}$ & $\begin{array}{c}4.87 \% \\
(13)\end{array}$ & $\begin{array}{c}19.48 \% \\
(52)\end{array}$ & $\begin{array}{c}44.19 \% \\
(118)\end{array}$ & $\begin{array}{c}29.96 \% \\
(80)\end{array}$ & $\begin{array}{c}0.00 \% \\
(0)\end{array}$ \\
\hline $\begin{array}{l}\text { Awareness And } \\
\text { Knowledge of } \\
\text { Cultural Differ- } \\
\text { ences }\end{array}$ & $\begin{array}{c}1.12 \% \\
(3)\end{array}$ & $\begin{array}{c}4.48 \% \\
(12)\end{array}$ & $\begin{array}{c}14.93 \% \\
(40)\end{array}$ & $\begin{array}{c}47.01 \% \\
(126)\end{array}$ & $\begin{array}{c}32.46 \% \\
(87)\end{array}$ & $\begin{array}{c}0.00 \% \\
(0)\end{array}$ \\
\hline $\begin{array}{l}\text { Inter-Cultural } \\
\text { Communication } \\
\text { Skills }\end{array}$ & $\begin{array}{c}1.13 \% \\
(3)\end{array}$ & $\begin{array}{c}3.02 \% \\
(8)\end{array}$ & $\begin{array}{c}12.83 \% \\
(34)\end{array}$ & $\begin{array}{c}46.79 \% \\
(124)\end{array}$ & $\begin{array}{c}36.23 \% \\
(96)\end{array}$ & $\begin{array}{c}0.00 \% \\
(0)\end{array}$ \\
\hline $\begin{array}{l}\text { Acceptance/ } \\
\text { Respectful- } \\
\text { ness/Tolerance } \\
\text { of Others }\end{array}$ & $\begin{array}{c}0.37 \% \\
\quad(1)\end{array}$ & $\begin{array}{c}1.12 \% \\
(3)\end{array}$ & $\begin{array}{c}7.46 \% \\
(20)\end{array}$ & $\begin{array}{c}38.81 \% \\
(104)\end{array}$ & $\begin{array}{c}51.49 \% \\
(138)\end{array}$ & $\begin{array}{c}0.75 \% \\
(2)\end{array}$ \\
\hline $\begin{array}{l}\text { Cognitive } \\
\text { Cultural } \\
\text { Intelligence }\end{array}$ & $\begin{array}{c}1.50 \% \\
(4)\end{array}$ & $\begin{array}{c}2.25 \% \\
(6)\end{array}$ & $\begin{array}{c}23.22 \% \\
\quad(62)\end{array}$ & $\begin{array}{c}45.69 \% \\
(122)\end{array}$ & $\begin{array}{c}26.22 \% \\
(70)\end{array}$ & $\begin{array}{c}1.12 \% \\
(3)\end{array}$ \\
\hline $\begin{array}{l}\text { Behavioral } \\
\text { Cultural } \\
\text { Intelligence }\end{array}$ & $\begin{array}{c}1.13 \% \\
(3)\end{array}$ & $\begin{array}{c}3.38 \% \\
(9)\end{array}$ & $\begin{array}{c}18.05 \% \\
(48)\end{array}$ & $\begin{array}{c}48.50 \% \\
(129)\end{array}$ & $\begin{array}{c}28.20 \% \\
(75)\end{array}$ & $0.75 \%$ \\
\hline Motivational & $1.50 \%$ & $4.14 \%$ & $19.55 \%$ & $47.37 \%$ & $26.32 \%$ & $15 \%$ \\
\hline
\end{tabular}




\begin{tabular}{lcccccc}
\hline Cultural & $(4)$ & $(11)$ & $(52)$ & $(126)$ & $(70)$ & $(3)$ \\
Intelligence & & & & & & \\
Inter-Cultural & $1.51 \%$ & $3.40 \%$ & $22.26 \%$ & $44.91 \%$ & $26.42 \%$ & $1.51 \%$ \\
Interaction & $(4)$ & $(9)$ & $(59)$ & $(119)$ & $(70)$ & $(4)$ \\
Skills & & & & & \\
Cultural Agility & $1.51 \%$ & $3.02 \%$ & $14.72 \%$ & $50.19 \%$ & $29.43 \%$ & $1.13 \%$ \\
& $(4)$ & $(8)$ & $(39)$ & $(133)$ & $(78)$ & $(3)$ \\
& & & & & & \\
Cross-Cultural & $1.51 \%$ & $3.40 \%$ & $16.60 \%$ & $46.42 \%$ & $31.70 \%$ & $0.38 \%$ \\
Competencies & $(4)$ & $(9)$ & $(44)$ & $(123)$ & $(84)$ & $(1)$ \\
and Skills & & & & & & \\
Cross-Cultural & $1.50 \%$ & $4.14 \%$ & $18.42 \%$ & $43.61 \%$ & $30.08 \%$ & $2.26 \%$ \\
Effective-Ness & $(4)$ & $(11)$ & $(49)$ & $(116)$ & $(80)$ & $(6)$ \\
& & & & & \\
Inter-Cultural & $1.89 \%$ & $3.03 \%$ & $15.53 \%$ & $54.55 \%$ & $23.86 \%$ & $1.14 \%$ \\
Adapt-Ability & $(5)$ & $(8)$ & $(41)$ & $(144)$ & $(63)$ & $(3)$ \\
& & & & & \\
\hline
\end{tabular}

On a behavioral level, in table 6, the element of "building trust" ranked highest with a percentage of a score of $67.42 \%$ in terms of importance, and "integrity" (64.9\%) was considered necessary.

Table 6: Behavioral competences

\begin{tabular}{lcccccc}
\hline $\begin{array}{l}\text { Behavioral } \\
\text { Competencies }\end{array}$ & $\begin{array}{c}\text { Not im- } \\
\text { portant }\end{array}$ & $\begin{array}{c}\text { Little im- } \\
\text { portant }\end{array}$ & $\begin{array}{c}\text { Average } \\
\text { important }\end{array}$ & $\begin{array}{c}\text { Very im- } \\
\text { portant }\end{array}$ & $\begin{array}{c}\text { Absolutely } \\
\text { important }\end{array}$ & $\begin{array}{c}\text { I don't } \\
\text { know }\end{array}$ \\
\hline Inter-Personal & $0.38 \%$ & $1.51 \%$ & $15.09 \%$ & $48.30 \%$ & $34.72 \%$ & $0.00 \%$ \\
Engagement & $(1)$ & $(4)$ & $(40)$ & $(128)$ & $(92)$ & $(0)$ \\
Social & $0.38 \%$ & $0.38 \%$ & $13.58 \%$ & $53.21 \%$ & $32.45 \%$ & $0.00 \%$ \\
Competence/So & $(1)$ & $(1)$ & $(36)$ & $(141)$ & $(86)$ & $(0)$ \\
cial Capital & & & & & & \\
Conflict & $0.38 \%$ & $2.26 \%$ & $13.21 \%$ & $40.38 \%$ & $43.40 \%$ & $0.38 \%$ \\
Management & $(1)$ & $(6)$ & $(35)$ & $(107)$ & $(115)$ & $(1)$ \\
Networking & $0.78 \%$ & $0.39 \%$ & $11.67 \%$ & $42.80 \%$ & $43.58 \%$ & $0.78 \%$ \\
Skills & $(2)$ & $(1)$ & $(30)$ & $(110)$ & $(112)$ & $(2)$ \\
& & & & & & \\
Integrity & $0.00 \%$ & $1.16 \%$ & $8.88 \%$ & $25.48 \%$ & $\mathbf{6 4 . 0 9 \%}$ & $0.39 \%$ \\
& $(0)$ & $(3)$ & $(23)$ & $(66)$ & $(166)$ & $(1)$ \\
Understanding & $1.15 \%$ & $4.58 \%$ & $27.86 \%$ & $47.71 \%$ & $18.70 \%$ & $0.00 \%$ \\
$\begin{array}{l}\text { Different Nego- } \\
\text { tiation Styles }\end{array}$ & $(3)$ & $(12)$ & $(73)$ & $(125)$ & $(49)$ & $(0)$ \\
\hline
\end{tabular}




\begin{tabular}{|c|c|c|c|c|c|c|}
\hline $\begin{array}{l}\text { Step Out of } \\
\text { Comfort Zone }\end{array}$ & $\begin{array}{c}0.38 \% \\
(1)\end{array}$ & $\begin{array}{c}0.38 \% \\
(1)\end{array}$ & $\begin{array}{c}12.55 \% \\
(33)\end{array}$ & $\begin{array}{c}46.39 \% \\
(122)\end{array}$ & $\begin{array}{c}39.92 \% \\
(105)\end{array}$ & $\begin{array}{c}0.38 \% \\
(1)\end{array}$ \\
\hline Building Trust & $\begin{array}{l}0.38 \% \\
\quad(1)\end{array}$ & $\begin{array}{l}0.38 \% \\
\quad(1)\end{array}$ & $\begin{array}{c}3.79 \% \\
(10)\end{array}$ & $\begin{array}{c}27.27 \% \\
\quad(72)\end{array}$ & $\begin{array}{c}67.42 \% \\
(178)\end{array}$ & $\begin{array}{c}0.76 \% \\
(2)\end{array}$ \\
\hline $\begin{array}{l}\text { Behavioral } \\
\text { Flexibility }\end{array}$ & $\begin{array}{l}0.76 \% \\
\quad(2)\end{array}$ & $\begin{array}{l}1.52 \% \\
(4)\end{array}$ & $\begin{array}{c}14.77 \% \\
(39)\end{array}$ & $\begin{array}{c}50.38 \% \\
(133)\end{array}$ & $\begin{array}{c}30.68 \% \\
(81)\end{array}$ & $\begin{array}{c}1.89 \% \\
(5)\end{array}$ \\
\hline $\begin{array}{l}\text { Cross-Border } \\
\text { Mobility }\end{array}$ & $\begin{array}{l}5.66 \% \\
(15)\end{array}$ & $\begin{array}{c}18.49 \% \\
(49)\end{array}$ & $\begin{array}{c}36.23 \% \\
(96)\end{array}$ & $\begin{array}{c}26.79 \% \\
(71)\end{array}$ & $\begin{array}{c}11.32 \% \\
(30)\end{array}$ & $\begin{array}{c}1.51 \% \\
(4)\end{array}$ \\
\hline $\begin{array}{l}\text { Listening, Re- } \\
\text { flecting and } \\
\text { Observation } \\
\text { Skills }\end{array}$ & $\begin{array}{l}0.38 \% \\
\quad(1)\end{array}$ & $\begin{array}{l}0.38 \% \\
\quad(1)\end{array}$ & $\begin{array}{c}6.08 \% \\
(16)\end{array}$ & $\begin{array}{c}41.44 \% \\
(109)\end{array}$ & $\begin{array}{c}50.95 \% \\
(134)\end{array}$ & $\begin{array}{c}0.76 \% \\
(2)\end{array}$ \\
\hline $\begin{array}{l}\text { Inter-Cultural } \\
\text { Adaptation }\end{array}$ & $\begin{array}{c}1.52 \% \\
(4)\end{array}$ & $\begin{array}{l}1.52 \% \\
(4)\end{array}$ & $\begin{array}{c}23.48 \% \\
(62)\end{array}$ & $\begin{array}{c}50.38 \% \\
(133)\end{array}$ & $\begin{array}{l}22.73 \% \\
\quad(60)\end{array}$ & $\begin{array}{c}0.38 \% \\
(1)\end{array}$ \\
\hline
\end{tabular}

In Table 7, we constructed the essential social skills measures that recognize emotional/affective measures, which is a fundamental competence a global leader with a global mindset, should exhibit. The variables "emotional intelligence" $(51.32 \%)$ and "open-mindedness" $(50 \%)$ were classified as absolute important.

Table 7: Emotional/Affective competencies

\begin{tabular}{|c|c|c|c|c|c|c|}
\hline $\begin{array}{l}\text { Emotional/ } \\
\text { Affective } \\
\text { Competencies }\end{array}$ & $\begin{array}{c}\text { Not } \\
\text { important }\end{array}$ & $\begin{array}{c}\text { Little } \\
\text { important }\end{array}$ & $\begin{array}{c}\text { Average } \\
\text { important }\end{array}$ & $\begin{array}{c}\text { Very } \\
\text { important }\end{array}$ & $\begin{array}{l}\text { Absolutely } \\
\text { important }\end{array}$ & $\begin{array}{l}\text { I don't } \\
\text { know }\end{array}$ \\
\hline $\begin{array}{l}\text { Open- } \\
\text { Mindedness/ } \\
\text { Openness }\end{array}$ & $\begin{array}{c}0.00 \% \\
(0)\end{array}$ & $\begin{array}{c}1.89 \% \\
(5)\end{array}$ & $\begin{array}{c}5.68 \% \\
(15)\end{array}$ & $\begin{array}{c}42.42 \% \\
(112)\end{array}$ & $\begin{array}{c}50.00 \% \\
(132)\end{array}$ & $\begin{array}{c}0.00 \% \\
(0)\end{array}$ \\
\hline $\begin{array}{l}\text { Emotional } \\
\text { Intelligence }\end{array}$ & $\begin{array}{l}0.00 \% \\
\quad(0)\end{array}$ & $\begin{array}{l}2.64 \% \\
\quad(7)\end{array}$ & $\begin{array}{l}4.53 \% \\
\quad(12)\end{array}$ & $\begin{array}{c}40.75 \% \\
(108)\end{array}$ & $\begin{array}{c}51.32 \% \\
(136)\end{array}$ & $\begin{array}{c}0.75 \% \\
\text { (2) }\end{array}$ \\
\hline $\begin{array}{l}\text { Emotional } \\
\text { Empathy/ } \\
\text { Emotional } \\
\text { Sensitivity }\end{array}$ & $\begin{array}{l}0.38 \% \\
\quad(1)\end{array}$ & $\begin{array}{c}1.89 \% \\
(5)\end{array}$ & $\begin{array}{c}7.17 \% \\
(19)\end{array}$ & $\begin{array}{c}47.55 \% \\
(126)\end{array}$ & $\begin{array}{c}42.64 \% \\
(113)\end{array}$ & $\begin{array}{c}0.38 \% \\
\quad(1)\end{array}$ \\
\hline $\begin{array}{l}\text { Humility/ } \\
\text { Humbleness }\end{array}$ & $\begin{array}{l}0.00 \% \\
\quad(0)\end{array}$ & $\begin{array}{l}2.28 \% \\
\quad(6)\end{array}$ & $\begin{array}{c}13.69 \% \\
(36)\end{array}$ & $\begin{array}{c}44.11 \% \\
(116)\end{array}$ & $\begin{array}{c}39.16 \% \\
(103)\end{array}$ & \\
\hline Curiosity & $0.76 \%$ & $0.76 \%$ & $10.27 \%$ & $41.83 \%$ & $45.63 \%$ & \\
\hline
\end{tabular}


(2)

Non-

Judgemental

Managing

Uncertainty

Risk-Taking

Patience

Appreciation

Of Others/

Diversity

Tolerance Of

Ambiguity

$$
\begin{gathered}
0.00 \% \\
(0) \\
0.75 \%
\end{gathered}
$$

(2)

$1.52 \%$

(4)

$0.38 \%$

(1)

$0.76 \%$

(2)

$1.14 \%$

(3)
(2)

$3.03 \%$

(8)

$1.89 \%$

(5)

$4.56 \%$

(12)

$2.26 \%$

(6)

$18.87 \%$

(50)

$1.91 \%$

$9.16 \%$

(24)

(5)

$1.14 \%$

(3)

$14.39 \%$

(38)

(68)
(110)

(120)

(2)

$51.89 \%$

$29.55 \%$

$1.52 \%$

(78)

(4)

(137)

$45.66 \%$

$1.13 \%$

(28) (106)

(121)

(3)

$25.86 \% \quad 43.73 \%$

(115)

$22.43 \%$

$1.90 \%$

(59)

(5)

$46.42 \%$

$30.57 \%$

$1.51 \%$

(81)

(4)

(123)

$44.66 \%$

$0.38 \%$

(113)

(117)

(1)

$47.35 \%$

$34.09 \%$

$1.89 \%$

$(90)$

(5)

The following Table 8 presents the findings from the other dimension of selfmanagement competencies. Overall, "self-reflection" (49.89\%) reached the highest value of absolute importance.

Table 8: Self-management competencies

\begin{tabular}{lcccccc}
\hline $\begin{array}{l}\text { Self- } \\
\text { Management } \\
\text { Competencies }\end{array}$ & $\begin{array}{c}\text { Not im- } \\
\text { portant }\end{array}$ & $\begin{array}{c}\text { Little im- } \\
\text { portant }\end{array}$ & $\begin{array}{c}\text { Average } \\
\text { important }\end{array}$ & $\begin{array}{c}\text { Very im- } \\
\text { portant }\end{array}$ & $\begin{array}{c}\text { Absolutely } \\
\text { important }\end{array}$ & $\begin{array}{c}\text { I don't } \\
\text { know }\end{array}$ \\
\hline Self-Awareness & $\begin{array}{c}0.38 \% \\
(1)\end{array}$ & $\begin{array}{c}0.38 \% \\
(1)\end{array}$ & $\begin{array}{c}6.79 \% \\
(18)\end{array}$ & $\begin{array}{c}50.19 \% \\
(133)\end{array}$ & $\begin{array}{c}42.26 \% \\
(112)\end{array}$ & $\begin{array}{c}0.00 \% \\
(0)\end{array}$ \\
Self- & $0.00 \%$ & $0.38 \%$ & $12.08 \%$ & $51.70 \%$ & $35.85 \%$ & $0.00 \%$ \\
Confidence & $(0)$ & $(1)$ & $(32)$ & $(137)$ & $(95)$ & $(0)$ \\
Self-Reflection & $0.00 \%$ & $0.75 \%$ & $10.94 \%$ & $38.49 \%$ & $49.81 \%$ & $0.00 \%$ \\
& $(0)$ & $(2)$ & $(29)$ & $(102)$ & $(\mathbf{1 3 2})$ & $(0)$ \\
Self-Regulation & $0.00 \%$ & $0.75 \%$ & $15.85 \%$ & $49.43 \%$ & $33.58 \%$ & $0.38 \%$ \\
& $(0)$ & $(2)$ & $(42)$ & $(131)$ & $(89)$ & $(1)$ \\
Self-Identity & $0.00 \%$ & $2.64 \%$ & $19.25 \%$ & $50.19 \%$ & $26.42 \%$ & $1.51 \%$ \\
& $(0)$ & $(7)$ & $(51)$ & $(133)$ & $(70)$ & $(4)$ \\
\hline
\end{tabular}




\begin{tabular}{|c|c|c|c|c|c|c|}
\hline $\begin{array}{l}\text { Positivity And } \\
\text { Optimism }\end{array}$ & $\begin{array}{c}0.00 \% \\
(0)\end{array}$ & $\begin{array}{c}1.13 \% \\
(3)\end{array}$ & $\begin{array}{c}10.57 \% \\
(28)\end{array}$ & $\begin{array}{c}47.17 \% \\
(125)\end{array}$ & $\begin{array}{c}41.13 \% \\
(109)\end{array}$ & $\begin{array}{c}0.00 \% \\
(0)\end{array}$ \\
\hline $\begin{array}{l}\text { Emotional } \\
\text { Resilience }\end{array}$ & $\begin{array}{c}0.00 \% \\
(0)\end{array}$ & $\begin{array}{c}1.52 \% \\
(4)\end{array}$ & $\begin{array}{c}8.71 \% \\
(23)\end{array}$ & $\begin{array}{c}43.94 \% \\
(116)\end{array}$ & $\begin{array}{c}44.70 \% \\
(118)\end{array}$ & $\begin{array}{c}1.14 \% \\
\text { (3) }\end{array}$ \\
\hline Hardiness & $\begin{array}{c}0.00 \% \\
(0)\end{array}$ & $\begin{array}{c}1.90 \% \\
(5)\end{array}$ & $\begin{array}{c}12.55 \% \\
(33)\end{array}$ & $\begin{array}{c}46.39 \% \\
(122)\end{array}$ & $\begin{array}{c}38.78 \% \\
(102)\end{array}$ & $\begin{array}{l}0.38 \% \\
\quad(1)\end{array}$ \\
\hline $\begin{array}{l}\text { Stress } \\
\text { Management }\end{array}$ & $\begin{array}{c}0.76 \% \\
(2)\end{array}$ & $\begin{array}{c}1.52 \% \\
(4)\end{array}$ & $\begin{array}{c}13.31 \% \\
(35)\end{array}$ & $\begin{array}{c}43.73 \% \\
(115)\end{array}$ & $\begin{array}{c}40.30 \% \\
(106)\end{array}$ & $\begin{array}{l}0.38 \% \\
\quad(1)\end{array}$ \\
\hline $\begin{array}{l}\text { Energy } \\
\text { Management }\end{array}$ & $\begin{array}{c}0.76 \% \\
(2)\end{array}$ & $\begin{array}{c}1.89 \% \\
(5)\end{array}$ & $\begin{array}{c}13.26 \% \\
(35)\end{array}$ & $\begin{array}{c}44.70 \% \\
(118)\end{array}$ & $\begin{array}{c}39.39 \% \\
(104)\end{array}$ & $\begin{array}{c}0.00 \% \\
(0)\end{array}$ \\
\hline $\begin{array}{l}\text { Work-Life } \\
\text { Balance }\end{array}$ & $\begin{array}{c}0.75 \% \\
(2)\end{array}$ & $\begin{array}{c}5.28 \% \\
(14)\end{array}$ & $\begin{array}{c}20.75 \% \\
\quad(55)\end{array}$ & $\begin{array}{c}49.43 \% \\
(131)\end{array}$ & $\begin{array}{l}23.40 \% \\
\quad(62)\end{array}$ & $\begin{array}{l}0.38 \% \\
\quad(1)\end{array}$ \\
\hline Self-Efficacy & $\begin{array}{c}0.00 \% \\
(0)\end{array}$ & $\begin{array}{l}2.26 \% \\
(6)\end{array}$ & $\begin{array}{c}12.83 \% \\
(34)\end{array}$ & $\begin{array}{c}55.85 \% \\
(148)\end{array}$ & $\begin{array}{c}27.92 \% \\
(74)\end{array}$ & $\begin{array}{c}1.13 \% \\
(3)\end{array}$ \\
\hline
\end{tabular}

The following Table 9 illustrates the survey findings on Global Leadership skills. Since there is no universal consensus on global leadership competencies, our survey results revealed characteristics for leading organizations. Firstly, "customer orientation" (55.89\%), "leading change" (54.34\%), and "empowering others" emerged as the absolute critical top three core competencies of global leadership skills.

Table 9: Global leadership competencies

\begin{tabular}{lcccccc}
\hline $\begin{array}{l}\text { Global Lead- } \\
\text { ership } \\
\text { Competen- } \\
\text { cies }\end{array}$ & $\begin{array}{c}\text { Not im- } \\
\text { portant }\end{array}$ & $\begin{array}{c}\text { Little } \\
\text { important }\end{array}$ & $\begin{array}{c}\text { Average } \\
\text { important }\end{array}$ & $\begin{array}{c}\text { Very } \\
\text { important }\end{array}$ & $\begin{array}{c}\text { Absolutely } \\
\text { important }\end{array}$ & $\begin{array}{c}\text { I don't } \\
\text { know }\end{array}$ \\
\hline $\begin{array}{l}\text { Leading Re- } \\
\text { mote/ Lead- }\end{array}$ & $4.55 \%$ & $3.03 \%$ & $7.95 \%$ & $35.23 \%$ & $\mathbf{4 8 . 1 1 \%}$ & $1.14 \%$ \\
ing Global & $(12)$ & $(8)$ & $(21)$ & $(93)$ & $\mathbf{( 1 2 7 )}$ & $(3)$ \\
Virtual & & & & & & \\
Teams & & & & & & \\
\end{tabular}

$\begin{array}{lcccccc}\text { Building } & 4.91 \% & 7.17 \% & 15.09 \% & 37.74 \% & 33.58 \% & 1.51 \% \\ \text { Global } & (13) & (19) & (40) & (100) & (89) & (4)\end{array}$

Business

Teams 


\begin{tabular}{|c|c|c|c|c|c|c|}
\hline $\begin{array}{l}\text { Collaboration } \\
\text { In Global } \\
\text { Teams }\end{array}$ & $\begin{array}{c}4.91 \% \\
(13)\end{array}$ & $\begin{array}{c}7.17 \% \\
(19)\end{array}$ & $\begin{array}{c}15.09 \% \\
(40)\end{array}$ & $\begin{array}{c}37.74 \% \\
(100)\end{array}$ & $\begin{array}{c}33.58 \% \\
(89)\end{array}$ & $\begin{array}{c}1.51 \% \\
(4)\end{array}$ \\
\hline $\begin{array}{l}\text { Visioning/Pr } \\
\text { oviding } \\
\text { Direction }\end{array}$ & $\begin{array}{c}1.89 \% \\
(5)\end{array}$ & $\begin{array}{c}3.41 \% \\
\quad(9)\end{array}$ & $\begin{array}{c}7.20 \% \\
(19)\end{array}$ & $\begin{array}{c}44.32 \% \\
(117)\end{array}$ & $\begin{array}{c}42.42 \% \\
(112)\end{array}$ & $\begin{array}{l}0.76 \% \\
\quad(2)\end{array}$ \\
\hline $\begin{array}{l}\text { Empowering } \\
\text { Others }\end{array}$ & $\begin{array}{c}1.14 \% \\
(3)\end{array}$ & $\begin{array}{c}1.89 \% \\
(5)\end{array}$ & $\begin{array}{c}7.58 \% \\
(20)\end{array}$ & $\begin{array}{l}36.74 \% \\
\quad(97)\end{array}$ & $\begin{array}{c}51.14 \% \\
(135)\end{array}$ & $\begin{array}{c}1.52 \% \\
\text { (4) }\end{array}$ \\
\hline $\begin{array}{l}\text { Rewarding } \\
\text { And Giving } \\
\text { Feedback }\end{array}$ & $\begin{array}{c}1.52 \% \\
(4)\end{array}$ & $\begin{array}{c}2.27 \% \\
(6)\end{array}$ & $\begin{array}{c}7.58 \% \\
(20)\end{array}$ & $\begin{array}{c}40.91 \% \\
(108)\end{array}$ & $\begin{array}{c}46.97 \% \\
(124)\end{array}$ & $\begin{array}{c}0.76 \% \\
\quad(2)\end{array}$ \\
\hline $\begin{array}{l}\text { Persistence } \\
\text { Leading } \\
\text { Change }\end{array}$ & $\begin{array}{l}0.76 \% \\
(2) \\
1.89 \% \\
(5)\end{array}$ & $\begin{array}{l}3.03 \% \\
\quad(8) \\
1.13 \% \\
(3)\end{array}$ & $\begin{array}{c}21.59 \% \\
(57) \\
5.28 \% \\
(14)\end{array}$ & $\begin{array}{c}46.59 \% \\
(123) \\
36.23 \% \\
(96)\end{array}$ & $\begin{array}{c}26.14 \% \\
(69) \\
\mathbf{5 4 . 3 4 \%} \\
(144)\end{array}$ & $\begin{array}{c}1.89 \% \\
(5) \\
1.13 \% \\
(3)\end{array}$ \\
\hline $\begin{array}{l}\text { Global Talent } \\
\text { Management }\end{array}$ & $\begin{array}{c}3.40 \% \\
(9)\end{array}$ & $\begin{array}{l}5.28 \% \\
(14)\end{array}$ & $\begin{array}{c}16.60 \% \\
(44)\end{array}$ & $\begin{array}{c}41.13 \% \\
(109)\end{array}$ & $\begin{array}{c}32.83 \% \\
\quad(87)\end{array}$ & $\begin{array}{l}0.75 \% \\
\quad(2)\end{array}$ \\
\hline $\begin{array}{l}\text { Fostering } \\
\text { Innovation }\end{array}$ & $\begin{array}{c}1.15 \% \\
(3)\end{array}$ & $\begin{array}{l}3.45 \% \\
\quad(9)\end{array}$ & $\begin{array}{c}19.54 \% \\
(51)\end{array}$ & $\begin{array}{c}40.23 \% \\
(105)\end{array}$ & $\begin{array}{c}34.10 \% \\
(89)\end{array}$ & $\begin{array}{c}1.53 \% \\
\text { (4) }\end{array}$ \\
\hline $\begin{array}{l}\text { Influencing } \\
\text { Stake- } \\
\text { Holders }\end{array}$ & $\begin{array}{l}0.76 \% \\
(2)\end{array}$ & $\begin{array}{c}1.52 \% \\
(4)\end{array}$ & $\begin{array}{c}12.88 \% \\
(34)\end{array}$ & $\begin{array}{c}40.15 \% \\
(106)\end{array}$ & $\begin{array}{c}43.56 \% \\
(115)\end{array}$ & $\begin{array}{c}1.14 \% \\
(3)\end{array}$ \\
\hline $\begin{array}{l}\text { Ethical and } \\
\text { Responsible/ } \\
\text { Vale Based } \\
\text { Global Lead- } \\
\text { er }\end{array}$ & $\begin{array}{l}2.65 \% \\
\quad(7)\end{array}$ & $\begin{array}{c}1.89 \% \\
(5)\end{array}$ & $\begin{array}{c}14.39 \% \\
(38)\end{array}$ & $\begin{array}{c}40.91 \% \\
(108)\end{array}$ & $\begin{array}{c}38.26 \% \\
(101)\end{array}$ & $\begin{array}{c}1.89 \% \\
(5)\end{array}$ \\
\hline $\begin{array}{l}\text { Perspective } \\
\text { Taking }\end{array}$ & $\begin{array}{l}0.38 \% \\
\quad(1)\end{array}$ & $\begin{array}{l}2.26 \% \\
(6)\end{array}$ & $\begin{array}{c}11.70 \% \\
(31)\end{array}$ & $\begin{array}{c}53.21 \% \\
(141)\end{array}$ & $\begin{array}{c}31.70 \% \\
(84)\end{array}$ & $\begin{array}{l}0.75 \% \\
\quad(2)\end{array}$ \\
\hline Diplomacy & $\begin{array}{l}0.75 \% \\
(2)\end{array}$ & $\begin{array}{c}2.26 \% \\
(6)\end{array}$ & $\begin{array}{c}14.72 \% \\
(39)\end{array}$ & $\begin{array}{c}48.68 \% \\
(129)\end{array}$ & $\begin{array}{c}32.83 \% \\
(87)\end{array}$ & $\begin{array}{l}0.75 \% \\
\quad(2)\end{array}$ \\
\hline $\begin{array}{l}\text { Customer } \\
\text { Orientation } \\
\text { Motivating }\end{array}$ & $\begin{array}{c}1.14 \% \\
(3) \\
1.51 \%\end{array}$ & $\begin{array}{l}0.76 \% \\
\quad(2) \\
0.75 \%\end{array}$ & $\begin{array}{c}7.22 \% \\
(19) \\
8.30 \%\end{array}$ & $\begin{array}{c}33.84 \% \\
(89) \\
46.79 \%\end{array}$ & $\begin{array}{c}55.89 \% \\
\mathbf{( 1 4 7 )} \\
41.89 \%\end{array}$ & $\begin{array}{c}1.14 \% \\
(3) \\
0.75 \%\end{array}$ \\
\hline
\end{tabular}




\begin{tabular}{lcccccc}
\hline And & $(4)$ & $(2)$ & $(22)$ & $(124)$ & $(111)$ & $(2)$ \\
$\begin{array}{l}\text { Engaging } \\
\text { Skills }\end{array}$ & & & & & & \\
Coaching and & $1.90 \%$ & $0.76 \%$ & $14.45 \%$ & $43.35 \%$ & $38.78 \%$ & $0.76 \%$ \\
$\begin{array}{l}\text { Mentoring } \\
\text { Skills }\end{array}$ & $(5)$ & $(2)$ & $(38)$ & $(114)$ & $(102)$ & $(2)$ \\
\hline
\end{tabular}

Overall, within the context of Global HR, the following GLM competencies emerged as of fundamental importance. Here we provide a Top 10 list. One is the highest in value of the top 10 list.

1. Willingness to understand others: Understanding others' feeling is a catalyst for interpersonal relationships.

2. Building trust: Trust is essential to a team's ability to share ideas openly, collaborate willingly, and contribute without reservation.

3. Cognitive complexity: Reflects an ability to see multiple perspectives and consider ideas, people, and situations from various angles. It is a prerequisite for developing a Global Leadership mindset on an individual level.

4. Complex problem-solving skills: To solve problems effectively, Global Leaders need to understand the real problems and make the right decisions at the right time.

5. Learning agility: The assessment of learning agility is a critical component of talent management practices in most organizations nowadays.

6. Customer orientation: A strategy requires companies to focus on their customers' changing needs and wants also relating to customer satisfaction.

7. Integrity: Requires having upstanding character traits and work ethics, which includes sound judgement, honesty, and strong moral principles.

8. Leading change is defined as leading individuals, teams, and organizations to new ways of doing things, build the capacity to learn and adapt.

9. Curiosity is described as a desire to learn something new. Beechler and Javidan (2007) relate curiosity to a general interest in other cultures. Curiosity for cultures can be added to curiosity for people (Beechler and Baltzley 2008, 43).

10. Cognitive Flexibility is a multi-dimensional construct at management level.

Finally, to develop Global Leaders, the HR functions should consider major roles to know what Global knowledge, skills, abilities, and attitudes are essential 
for global corporations' leaders. If research could identify the critical GLM competencies, corporations might shorten the extended period for developing Global Leaders and reducing training costs within the Global HR function (Muratbekova-Touron 2009).

\section{DisCuSSION OF FINDINGS AND DERIVATION OF A CONCEPTUAL MODEL OF GLM DEVELOPMENT IN HR}

Our study proposed the top ten GLM HR competencies highlighted as proxy measures to demonstrate essential skill sets required for individuals within the Global HR function. Our research findings are consistent with other studies that emphasize the importance of cultural knowledge (Osland 1995, Adler 1997) and the individual's cognitive skills fundamental for GLM's success (Levy et al. 1999). Existing studies highlight three core GLM competencies, such as importance of influencing others, making ethical decisions, and leading change (Bass and Steidlmeier 1999, Canterino, Cirella, Piccoli and Shani 2020), but only a few studies focus on the assessment or testing of these GLM competencies (e.g., Herd, Alagaraja and Cumberland 2016, Cumberland et al. 2016, Kim and Mclean 2015). Hence, our study attempted to elucidate the fundamentals underlying GLM skills and competency development, using multiple functional global HR roles to identify the significance of the competencies discussed in this study. For descriptive analysis, we extrapolated different twelve HR roles on different leadership levels using descriptive statistics (mean, mode and median) of the different layers of skills for each of the roles in Appendix 1. In order to identify patterns, and distinctions among GLM competencies on certain organizational levels within the HR department, the twelve positions under study were clustered into three leadership stages:

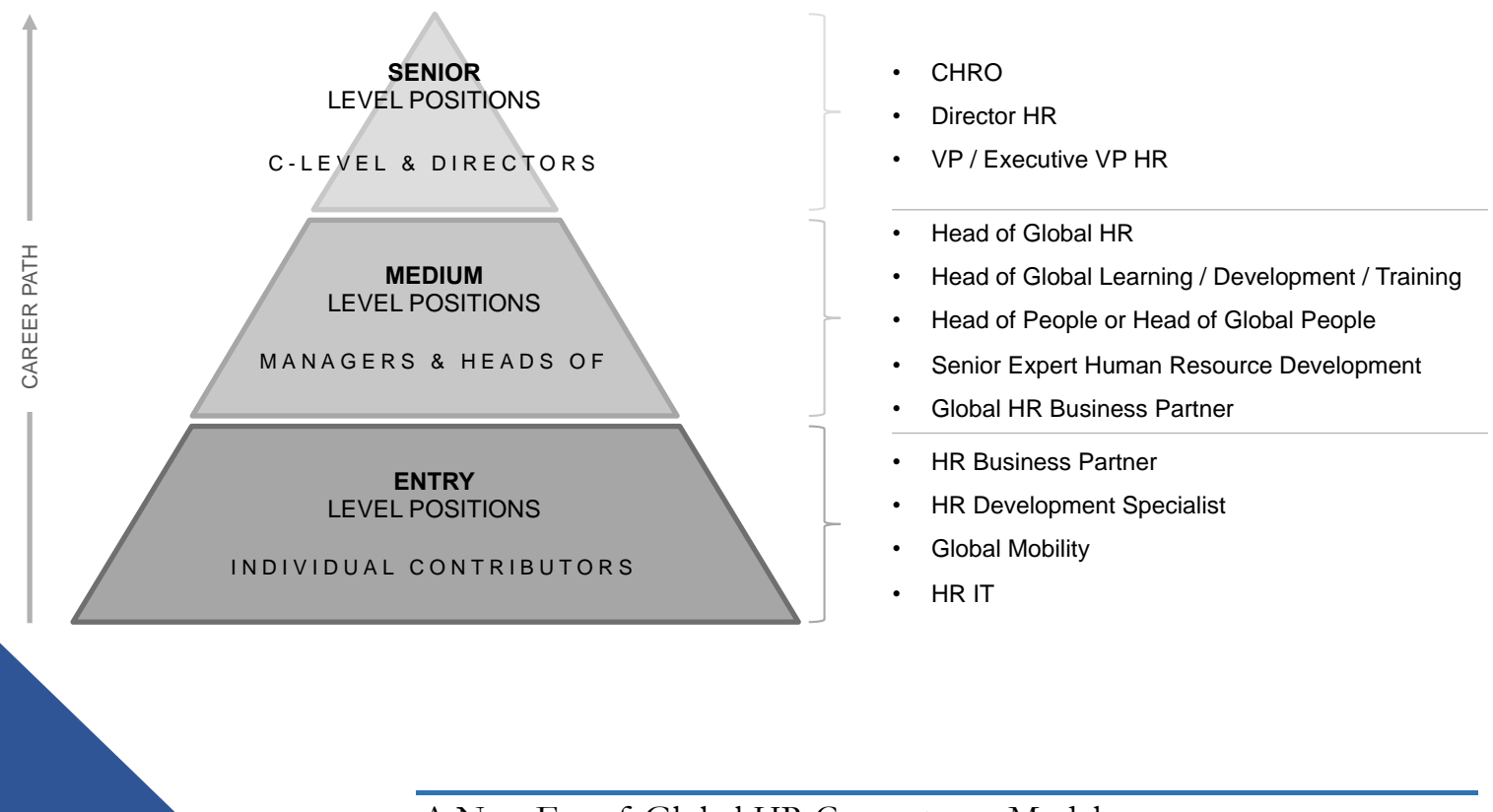

A New Era of Global HR Competency Model 
Figure 3: Positional levels in HR

The first level of HR positions includes four entry-level positions: (1) HR Business Partner, (2) HR Development Specialist, (3) Global Mobility, and (4) HR IT. The second level comprises five managers and Heads of global roles with a work experience of 5 to 10 years. The Head of Global HR, Head of Global Learning / Development / Training, Head of People or Head of Global People, Senior Expert Human Resource Development, and Global HR Business Partner are listed. Lastly, the senior-level positions contain the Corporatelevel executives and directors: (1) CHRO, (2) Director HR, and (3) Vice President / Executive VP HR. By consolidating the underlying survey data according to the formed levels of HR positions on a global career path, we can gain insights into potential discrepancies between required GLM competencies at different stages. Thus, potential learnings for the focus of HR development efforts to nurture relevant competencies at different positional levels can be derived. While acknowledging the statistical insignificance of such analysis, the consideration of the average, assigned importance of each competency included in the survey draws an interesting picture. For example, cognitive complexity is the competency with the highest average score in importance across entrylevel respondents, while it does not occur in the top 10 among senior level participants. On the other hand, willingness to understand others, building trust, and complex problem-solving skills seem to be skills of great importance across all levels of HR positions. As shown in table 10, the survey data show distinct differences in which competency category is essential at which organizational/ leadership level. While for entry-level positions, self-management skills, emotional/affective, and cognitive competencies are most important global leadership skills play a vital role in medium-level positions. At the senior level, the emotional/affective competencies are the most relevant above all, followed by cognitive aspects. Interestingly, cultural competencies have been assigned the lowest importance across all levels. Here, the complexity of culture becomes evident, as the exposure varies considerably across multiple business functions. In practice, entry-level positions such as (1) HR Business Partner, (2) HR Development Specialist, (3) Global Mobility, and (4) HR IT held by recent university graduates and career starters involve acclimatization to the business environment. At the medium level positions, such as (1) Head of Global HR, (2) Head of Global Learning / Development / Training, (3) Head of People or Head of Global People, (4) Senior Expert Human Resource Development, and (5) Global HR Business Partner individuals are entrusted with first management tasks and leadership roles, referring to global leadership skills as most relevant. The senior executives at the top level, such as (1) CHRO, (2) Director HR, and (3) Vice President / Executive VP HR, find themselyes 
exposed to the need to fulfill stakeholder expectations and make more complex and challenging decisions, which could well be the reason for emotional and cognitive competencies to be top of the list.

\section{CONCLUSION, LIMITATIONS, IMPLICATIONS AND FUTURE RESEARCH}

The findings of this study expand on previous research on GLM development. Our study has made a significant contribution in the field of GLM HR development. Firstly, the empirical study focused on global HR as a proxy to identify and measure competencies individuals require to develop GLM capabilities. However, since there is no isolated variable required for GLM development, in our study, we were able to identify 75 GLM competencies, of which we clustered them to have six dimensions (cognitive, affective, behavioral, cultural, self-management, global leadership skills) to observe these skills. The results may also help explain organizations' complexity in finding the right balance between GLM development and HR personnel. More studies are required to understand what organizations need to do when developing best-fit GLM development programs for their employees. There are some underlining limitations within this study when interpreting the research findings. Firstly, the sample size of 256 respondents is not very representative of the concepts under study. While increasing the scope of the sample, findings could reveal another pattern regarding GLM development. Our study could also benefit from a longitudinal design to assess the individuals' GLM development over a period. Another limitation to this study is that the assessment of GLM competencies was selfrated, limiting bias or skewing the research findings. However, to minimize this, we also propose that future studies increase the sampling scope size and gather additional ratings from senior management, which can measure GLM competencies. However, our study has some practical implications for the global HR managers when selecting, promoting, and assigning individuals of a global nature. Based on the dimensions that have been identified global HR managers can be able to identify the "tool-kit" of GLM skills essential for international assignments. The use of appraisal methods such as behaviourally anchored rating scale can be an effective instrument to determine whether individuals can engage in cross-border assignments. Therefore, organizations should identify those GLM program individuals who can score on multiple meta-competencies and use this as a precursor to GLM development programs. Furthermore, organizations need to be aware that the cultivation of a GLM requires personality traits and specific GLM competencies. Furthermore, measuring a GLM also depends on the selection and training of individuals from HR professionals 
providing to employees. Organizations thus, need to examine which dimension has more impact on the global leaders' performance. As the field of human resources development continues to expand, there will be an ongoing need to synthesize empirical studies to help practitioners successfully select and groom future leaders. Global HR managers need to ascertain that a one-size fits not all approach in GLM development programs is adequate. Secondly, addressing a wide array of leadership development competencies is vital in creating more bespoke training solutions for organizations. We would also propose the future studies examine the topic under discussion by focusing on multinational companies in different regions such as emerging countries. These companies have a more diverse HR department, and observational variables for GLM development will include multiple factors and allow researchers to run ANOVA. This statistical technique will capture significant differences (competence levels) among potential individuals who may qualify for GLM development programs within their organizations.

\section{REFERENCES}

Adler, N. J. (1997). International Dimensions of Organizational Behaviour South. Western College Publishing: Cincinnati, Ohio, 164, 101-114.

Andresen, M., \& Bergdolt, F. (2017). A systematic literature review on the definitions of global mindset and cultural intelligence-merging two different research streams. The International Journal of Human Resource Management, 28(1), 170-195.

Bass, B. M., \& Steidlmeier, P. (1999). Ethics, character, and authentic transformational leadership behavior. The leadership quarterly, 10(2), 181-217.

Beechler, S., \& Javidan, M. (2007). Leading with a global mindset. In The global mindset. Emerald Group Publishing Limited.

Bird, A., Osland, J. S., \& Lane, H. W. (2004). Global competencies: An introduction. The Blackwell handbook of global management: A guide to managing complexity, 57-80.

Bird, A. (2013). Mapping the content domain of global leadership competencies. In Global leadership $2 e$ (pp. 92-108). Routledge.

Bird, A., \& Stevens, M. J. (2013). Assessing global leadership competencies. In Global Leadership $2 e$ (pp. 125-152). Routledge.

Black, J. S. (1999). Globalizing people through international assignements. Addison-Wesley.

Blancero, D., Boroski, J., \& Dyer, L. (1996). Key competencies for a transformed human resource organization: Results of a field study. Human resource management, 35(3), 383-403.

Bohas, A., Morley, M. J., \& Kinra, A. (2021). Perlmutter revisited: Revealing the anomic mindset. Journal of International Business Studies, 1-29.

Brake, T. (1997). The global leader: Critical factors for creating the world class organization. Irwin Professional.

Caligiuri, P. (2006). Developing global leaders. Human Resource Management Review, 16(2), 219-228.

International Journal of Community Development and Management Studies 
Caligiuri, P., \& Tarique, I. (2012). Dynamic cross-cultural competencies and global leadership effectiveness. Journal of world Business, 47(4), 612-622.

Caligiuri, P., \& Tarique, I. (2014). Individual-level accelerators of global leadership development. In Advances in global leadership. Emerald Group Publishing Limited.

Canterino, F., Cirella, S., Piccoli, B., \& Shani, A. B. R. (2020). Leadership and change mobilization: The mediating role of distributed leadership. Journal of Business Research, 108, $42-51$.

Cohen, D. J. (2015). HR past, present and future: A call for consistent practices and a focus on competencies. Human Resource Management Review, 25(2), 205-215.

Cseh, M., Davis, E. B., \& Khilji, S. E. (2013). Developing a global mindset: Learning of global leaders. European Journal of Training and Development. 37(5): 489-499.

Cumberland, D. M., Herd, A., Alagaraja, M., \& Kerrick, S. A. (2016). Assessment and development of global leadership competencies in the workplace: A review of literature. Advances in Developing Human Resources, 18(3), 301-317.

Dalton, M. A., \& Ernst, C. (1998). Developing leaders for global roles. The center for creative leadership bandbook of leadership development, 379-402.

Den Dekker, W. (2016). Global mindset and cross-cultural behavior: Improving leadership effectiveness. Springer.

Eichinger, R., \& Lombardo, M. (2015). Twenty-two ways to develop leadership in staff managers. Center for Creative leadership.

Felício, J. A., Caldeirinha, V. R., \& Rodrigues, R. (2012). Global mindset and the internationalization of small firms: The importance of the characteristics of entrepreneurs. International Entrepreneurship and Management Journal, 8(4), 467-485.

Felício, J. A., Caldeirinha, V. R., Rodrigues, R., \& Kyvik, O. (2013). Cross-cultural analysis of the global mindset and the internationalization behavior of small firms. International Entrepreneurship and Management Journal, 9(4), 641-654.

Felício, J. A., Caldeirinha, V. R., \& Ribeiro-Navarrete, B. (2015). Corporate and individual global mind-set and internationalization of European SMEs. Journal of Business Research, 68(4), 797802.

Felício, J. A., Meidute, I., \& Kyvik, Ø. (2016). Global mindset, cultural context, and the internationalization of SMEs. Journal of Business Research, 69(11), 4924-4932.

Goldsmith, M., Greenberg, C., Robertson, A., \& Hu-Chan, M. (2003). Global leadership: The next generation. Ft Press.

Goleman, D. (1995). Emotional Intelligence New York. NY: Bantam Books.

Gupta, A. K., \& Govindarajan, V. (2002). Cultivating a global mindset. Academy of Management Perspectives, 16(1), 116-126.

Gupta, A. K., Govindarajan, V., \& Wang, H. (2008). The quest for global dominance: Transforming global presence into global competitive advantage. John Wiley \& Sons.

Harris, P. R., Moran, R. T., \& Moran, S. V. (2004). Managing Cultural Differences. Global Leadership Strategies for the 21st Century (Managing Cultural Differences Series). Butterworth-Heinemann.

Henson, R. (2016). Building an organizational global mindset culture: Implications for practice. In Successful global leadership (pp. 261-283). Palgrave Macmillan, New York. 
Herd, A. M., Alagaraja, M., \& Cumberland, D. M. (2016). Assessing global leadership competencies: the critical role of assessment centre methodology. Human Resource Development International, 19(1), 27-43.

Hruby, J., Watkins-Mathys, L., \& Hanke, T. (2016). Antecedents and outcomes of a global mindset: A thematic analysis of research from 1994 to 2013 and future research agenda. In Advances in global leadership. Emerald Group Publishing Limited.

Hruby, J., de Melo, R. J., Samunderu, E., \& Hartel, J. (2018). Unpacking the complexities of global mindset: A multi-lens analysis. In Advances in global leadership. Emerald Publishing Limited.

Huesing, B. (2016). The Nature of Global Leaders' Work: A Dissertation Submitted in Partial Fulfillment of the Requirements for the Degree of Doctor of Philosophy in Values-Driven Leadership (Doctoral dissertation, Benedictine University).

Huesing, T., \& Ludema, J. 2017. The nature of global leaders' work. In J. S. Osland, M. E. Mendenhall, \& M. Li (Eds.), Advances in global leadership in Full 10: 3-39. Bingley: Emerald.

IBM. 2010. Global CHRO Study, Working beyond Borders. Ibm.com/working beyond borders.

Javidan, M., \& Walker, J. L. (2012). A whole new global mindset for leadership. People and Strategy, 35(2), 36

Javidan, M., \& Walker, J. L. (2013). Developing your global mindset: the handbook for successful global leaders. Beaver's Pond Press, Incorporated.

Javidan, M., \& Bowen, D. (2013). The 'global mindset'of managers. Organizational Dynamics, 42(2), $145-155$.

Johnson, J. P., Lenartowicz, T., \& Apud, S. (2006). Cross-cultural competence in international business: Toward a definition and a model. Journal of international business studies, 37(4), 525-543.

Jokinen, T. (2005). Global leadership competencies: a review and discussion. Journal of European industrial training.

Kedia, B. L., \& Mukherji, A. (1999). Global managers: developing a mindset for global competitiveness. Journal of world Business, 34(3), 230-251.

Kim, J., \& McLean, G. N. (2015). An integrative framework for global leadership competency: Levels and dimensions. Human Resource Development International, 18(3), 235-258.

Kohont, A., \& Brewster, C. (2014). The roles and competencies of HR managers in Slovenian multinational companies. Baltic Journal of Management.

Kyvik, O., Saris, W., Bonet, E., \& Felício, J. A. (2013). The internationalization of small firms: The relationship between the global mindset and firms' internationalization behavior. Journal of International Entrepreneurship, 11(2), 172-195.

Kyvik, O. 2017. The global mindset and SME-internationalization-A systematic review-GIKA, 1-15.

Kyvik, O. (2018). The global mindset: A must for international innovation and entrepreneurship. International Entrepreneurship and Management Journal, 14(2), 309-327.

Levy, O., Beechler, S., Taylor, S., \& Boyacigiller, N. A. (2007). What we talk about when we talk about 'global mindset': Managerial cognition in multinational corporations. Journal of International Business Studies, 38(2), 231-258.

Lo, K., Macky, K., \& Pio, E. (2015). The HR competency requirements for strategic and functional HR practitioners. The International Journal of Human Resource Management, 26(18), 2308-2328.

Long, C. S., \& bin Wan Ismail, W. K. (2008). Human resource competencies: A study of the HR professionals in manufacturing firms in Malaysia. International Management Review, 4(2).

International Journal of Community Development and Management Studies 
Lovvorn, A. S., \& Chen, J. S. (2011). Developing a global mindset: The relationship between an international assignment and cultural intelligence. International Journal of Business and Social Science, 2(9).

Maznevski, M., Stahl, G. K., \& Mendenhall, M. E. (2013). Thematic issue: Towards an integration of global leadership practice and scholarship: Repairing disconnects and heightening mutual understanding introduction.

McCall, M. W., \& Hollenbeck, G. P. (2002). Developing global executives: The lessons of international experience. Harvard Business Press.

McClelland, D. C. (1973). Testing for competence rather than for" intelligence.". American psychologist, 28(1), 1.

Meldrum, M., \& Atkinson, S. (1998). Meta-abilities and the implementation of strategy: knowing what to do is simply not enough. Journal of Management Development.

Mendenhall, M. E. (2017). Leadership and the birth of global leadership. In Global Leadership (pp. 327). Routledge.

Mendenhall, M., \& Osland, J. (2002). Mapping the terrain of the global leadership construct. Academy of International Business, Puerto Rico, June, 29.

Mendenhall, M. E., Osland, J., Bird, A., Oddou, G. R., Stevens, M. J., Maznevski, M., \& Stahl, G. K. (Eds.). (2017). Global leadership: Research, practice, and development. Routledge.

Mendenhall, M. E., Li, M., \& Osland, J. S. (2016). Five years of global leadership research, 20102014: Patterns, themes, and future directions. In Advances in global leadership. Emerald Group Publishing Limited.

Mendenhall, M. E., Weber, T. J., Arnardottir, A. A., \& Oddou, G. R. (2017). Developing global leadership competencies: A process model. In Advances in global leadership. Emerald Publishing Limited.

Mendenhall, M. E., Burke-Smalley, L. A., Arnardottir, A. A., Oddou, G. R., \& Osland, J. S. (2020). Making a difference in the classroom: Developing global leadership competencies in business school students. In Research Handbook of Global Leadership. Edward Elgar Publishing.

Morrison, A. J. (2000). Developing a global leadership model. Human resource management, 39(2-3), 117131.

Mumford, T. V., Campion, M. A., \& Morgeson, F. P. (2007). The leadership skills strataplex: Leadership skill requirements across organizational levels. The Leadership Quarterly, 18(2), 154-166.

Muratbekova-Touron, M. (2009). Why a multinational company introduces a competency-based leadership model: a two-theory approach. The International Journal of Human Resource Management, 20(3), 606-632.

Osland, J. (1995). The adventure of working abroad: Hero tales from the global frontier. Jossey-Bass Publishers.

Osland, J. S., Bird, A., Mendenhall, M., \& Osland, A. (2006). 11 Developing global leadership capabilities and global mindset: a review. Handbook of research in international buman resource management, 197.

Osland, J. S. (2013). An overview of the global leadership literature. Global Leadership 2e, 52-91.

Osland, J. S., \& Bird, A. L. L. A. N. (2013). Process models of global leadership development. In Global Leadership $2 e$ (pp. 109-124). Routledge. 
Osland, J. S., 2018. An Overview of the Global Leadership Literature. In: M. E. Mendenhall, et al. eds. Global Leadership: Research, Practice and Development. New York: Routledge, 67-127.

Osland, J. S., Li, M., \& Mendenhall, M. E. (2017). Patterns, themes and future directions for advancing global leadership. In Advances in global leadership. Emerald Publishing Limited.

Osland, J. S., Mendenhall, M. E., Reiche, B. S., Szkudlarek, B., Bolden, R., Courtice, P., ... \& Maznevski, M. (2020). Perspectives on global leadership and the Covid-19 crisis. In Advances in Global Leadership. Emerald Publishing Limited.

Reiche, B. S., Bird, A., Mendenhall, M. E., \& Osland, J. S. (2017). Contextualizing leadership: A typology of global leadership roles. Journal of International Business Studies, 48(5), 552-572.

Rhinesmith, S. (2003). Global leadership and global emotional intelligence. The Many Facets of Leadership, Upper Saddle River, NJ: Financial Times Prentice Hall, 215-227.

Simmonds, D., \& Tsui, O. (2010). Effective design of a global leadership programme. Human Resource Development International, 13(5), 519-540.

Suutari, V. (2002). Global leader development: An emerging research agenda. Career Development International.

Ulrich, D., \& Brockbank, W. (2005). The HR value proposition. Harvard Business Press.

Wills, S., \& Barham, K. (1994). Being an international manager. European Management Journal, 12(1), 49-58.

Wiseman L. 2012, From international to global thinking, CMA Magazine.

Yeung, A., Woolcock, P., \& Sullivan, J. (1996). Identifying and developing HR competencies for the future. Human Resource Planning, 19(4), 48-58. 


\section{AUTHOR'S BIOGRAPHY}

Dr. Eyden Samunderu is a Professor at the International School of Management (ISM) Dortmund in Germany. His key research interests include air transport economics global leadership mindset development, leadership and change management.

Dr. Jörg Hruby is a graduate in Business Economics from the University of Duisburg-Essen and Doctorate from the Department of Organization and Economics of Institutions of the University of Graz, Austria. Jörg Hruby is one of the leading experts and authors in the field of Global Mindset.

Jingxian Wang graduated with a B.Sc. International Management from ISM Dortmund. She exchanged one semester abroad at Beijing Foreign Studies University, focusing on International Business major. She has lots of working experience as an intern at Siemens Power Automation (Nanjing), ZTE (Dusseldorf), and some other fields. Currently, she works in KPMG China.

Ingo Röger graduated from the Master program International Management at ISM in Dortmund and went on to put his learnings into practice as co-founder of an e-commerce agency. His research interest is in the field of global leadership. 